The University of Maine

\title{
DigitalCommons@UMaine
}

Earth Science Faculty Scholarship

Earth Sciences

9-1-1998

\section{Circum-Antarctic Coastal Environmental Shifts During the Late Quaternary Reflected by Emerged Marine Deposits}

Paul A. Berkman

John T.Andrews

Svante Björck

Eric A. Colhoun

Steven D. Emslie

See next page for additional authors

Follow this and additional works at: https://digitalcommons.library.umaine.edu/ers_facpub

Part of the Earth Sciences Commons

\section{Repository Citation}

Berkman, Paul A.; Andrews, John T.; Björck, Svante; Colhoun, Eric A.; Emslie, Steven D.; Goodwin, Ian D.; Hall, Brenda L.; Hart, Charles P.; Hirakawa, Kazuomi; Igarashi, Atsuo; Ingólffson, Olafur; Lopez-Martinez, Jeronimo; Lyons, W. Berry; Mabin, Mark C.G.; Quilty, Patrick G.; Taviani, Marco; and Yoshida, Yoshio, "Circum-Antarctic Coastal Environmental Shifts During the Late Quaternary Reflected by Emerged Marine Deposits" (1998). Earth Science Faculty Scholarship. 127.

https://digitalcommons.library.umaine.edu/ers_facpub/127

This Conference Proceeding is brought to you for free and open access by DigitalCommons@UMaine. It has been accepted for inclusion in Earth Science Faculty Scholarship by an authorized administrator of DigitalCommons@UMaine. For more information, please contact um.library.technical.services@maine.edu. 


\section{Authors}

Paul A. Berkman, John T. Andrews, Svante Björck, Eric A. Colhoun, Steven D. Emslie, Ian D. Goodwin, Brenda L. Hall, Charles P. Hart, Kazuomi Hirakawa, Atsuo Igarashi, Olafur Ingólffson, Jeronimo LopezMartinez, W. Berry Lyons, Mark C.G. Mabin, Patrick G. Quilty, Marco Taviani, and Yoshio Yoshida 


\title{
Circum-Antarctic coastal environmental shifts during the Late Quaternary reflected by emerged marine deposits
}

\author{
PAUL A. BERKMAN', JOHN T. ANDREWS ${ }^{2}$, SVANTE BJÖRCK³, ERIC A. COLHOUN ${ }^{4}$, STEVEN D. EMSLIE ${ }^{5}$, \\ IAN D. GOODWIN ${ }^{6}$, BRENDA L. HALL ${ }^{7}$, CHARLES P. HART ${ }^{2}$, KAZUOMI HIRAKAWA ${ }^{8}$, ATSUO IGARASHI ${ }^{9}$, \\ OLAFUR INGÓLFSSON ${ }^{10}$, JERONIMO LÓPEZ-MARTÍNEZ ${ }^{11}$, W. BERRY LYONS ${ }^{12}$, MARK C.G. MABIN ${ }^{13}$, \\ PATRICK G. QUILTY ${ }^{14}$, MARCO TAVIANI ${ }^{15}$ and YOSHIO YOSHIDA ${ }^{16}$
}

\author{
'Byrd Polar Research Center. The Ohio State University, 108 Scott Hall, 1090 Carmack Road, Columbus, OH 43210, USA \\ 'Institute of Arctic and Alpine Research and Department of Geological Sciences, Box 450. University of Colorado. Boulder. \\ CO 80309, USA \\ ${ }^{3}$ Geological Institute, University of Copenhagen, Oster Voldgade 10, DK-1350, Copenhagen, Denmark \\ 'Department of Geography and Environmental Science, University of Newcastle, Callaghan, NSW 2308, Australia \\ ${ }^{5}$ Department of Biological Sciences, University of North Carolina, 60I South College Road, Wilmington, NC 28403, USA \\ ${ }^{6}$ Antarctic CRC, GPO Box 252-80, Hobart, TAS 7001, Australia \\ 'Department of Geological Sciences and Institute of Quaternary Studies, University of Maine, Orono, ME 04469, USA \\ ${ }^{8}$ Earth Environmental Science, Hokkaido University, Kita 10, Nishi 5, Kita-Ku, Sapparo 060, Japan \\ 'Department of Polar Biology, National Institute of Polar Research, 9-10 Kaga, 1-Chome, Itabashi-ku, Tokyo 173. Japan \\ ${ }^{10}$ Earth Sciences Centre, University of Gothenburg, Guldhedsgatan Sa, S-41381 Gothenburg. Sweden \\ "Department of Geology, Facultad di Ciencias, Universidad Autonoma de Madrid, 28049 Madrid, Spain \\ ${ }^{12}$ Department of Geology, University of Alabama, Tuscaloosa, AL 35487. USA \\ ${ }^{13}$ Department of Tropical Environmental Studies and Geography, James Cook University of North Queensland, \\ Townsville, QLD 481 J, Australia \\ "Australian Antarctic Division, Channel Highway, Kingston, TAS 7050, Australia \\ ${ }^{15}$ Instituto di Geologia Marina, C.N.R., Via Gobetti 101, 1-40129 Bologna, Italy \\ ${ }^{16}$ Department of Geography, Rissho University, 4-2-16. Osaki, Shinagawa-ku, Tokyo 141, Japan
}

\begin{abstract}
This review assesses the circumpolar occurrence of emerged marine macrofossils and sediments from Antarctic coastal areas in relation to Late Quaternary climate changes. Radiocarbon ages of the macrofossils, which are interpreted in view of the complexities of the Antarctic marine radiocarbon reservoir and resolution of this dating technique, show a bimodal distribution. The data indicate that marine species inhabited coastal environments from at least 35000 to $20000 \mathrm{yr}$ BP, during Marine Isotope Stage 3 when extensive iceberg calving created a 'meltwater lid' over the Southern Ocean. The general absence of these marine species from 20000 to $8500 \mathrm{yr}$ BP coincides with the subsequent advance of the Antarctic ice sheets during the Last Glacial Maximum. Synchronous re-appearance of the Antarctic marine fossils in emerged beaches around the continent, all of which have Holocene marine-limit elevations an order of magnitude lower than those in the Arctic, reflect minimal isostatic rebound as relative sea-level rise decelerated. Antarctic coastal marine habitat changes around the continent also coincided with increasing sea-ice extent and outlet glacial advances during the mid-Holocene. In view of the diverse environmental changes that occurred around the Earth during this period, it is suggested that Antarctic coastal areas were responding to a mid-Holocene climatic shift associated with the hydrological cycle. This synthesis of Late Quaternary emerged marine deposits demonstrates the application of evaluating circum-Antarctic phenomena from the glacial-terrestrialmarine transition zone.
\end{abstract}

Received 2 January 1998, accepted 27 May $1998^{\circ}$

Key words: Antarctic, beaches, fossils, Holocene, Pleistocene, radiocarbon, sediments

\section{Introduction}

Antarctic coastal areas contain marine sediments and fossils which have emerged above sea level during the Late Pleistocene and Holocene. These emerged marine deposits, some of which have been studied since early in the 20th century (Anderson 1906, Ferrar 1907, David \& Priestly 1909, Debenham 1920), exist around the continent in environmental zones that are directly influenced by the prevailing glacial, marine and climate conditions. The purpose of this review article is to assess the coastal deposits in relation to circumAntarctic environmental shifts that may have occurred during the Late Quaternary.

Most of the Antarctic coastline is occupied by ice shelves, ice streams, ice walls and outlet glaciers (Table I). These glacial systems are, in turn, influenced by the relative dynamics of the adjacent ice sheets which vary from the land-based East 
Table I. Coastal types around the Antarctic margin'

\begin{tabular}{lcc}
\hline coastal type & coastline distance $(\mathrm{km})$ & coastline \% \\
\hline ice shelves & 14110 & 44 \\
ice walls & 12156 & 38 \\
ice strcams and outlet glaciers & 3954 & 13 \\
ice-free areas & 1656 & 5 \\
Total & 31876 & \\
\hline
\end{tabular}

'Modified from Drewry et al. 1982.

Antarctic Ice Sheet (Drewry 1975, Jacobs 1992) to the marinebased West Antarctic Ice Sheet (Mercer 1978, Denton et al. 1989, Alley \& Whillans 1991) to the ice masses in the Antarctic Peninsula region (Sugden \& Clapperton 1980, Rott et al. 1996). Because Antarctic coastal areas are directly impacted by these different ice sheets, any coastal environmental shifts which are synchronous around the continent would suggest an overriding imprint of climate change.

There also are climate feedbacks from the Antarctic ice sheets that influence adjacent coastal areas in a circumpolar context. Cold dry air masses over Antarctica create a zonal pressure gradient in the atmosphere that generates the polar vortex around the continent (Schwerdtfeger 1984, King \& Tumer 1997). This cyclonic circulation in the atmosphere, in turn, influences oceanic circulation and drives the Antarctic Circumpolar Current (Deacon 1937). The influence of these atmospheric processes also is reflected in the circumpolar band of snow accumulation within $500 \mathrm{~km}$ of the coastline, which has accumulation rates that are an order of magnitude higher than than on the polar plateau (Giovinetto \& Bentley 1985). The Antarctic ice sheets also exert an influence on sea- ice production, water mass formation and Antarctic marine ecosystem processes around the continent (Deacon 1982, Smith 1990).

Even though ice-free areas occupy only $5 \%$ of the coastline (Table I), there are hundreds of Late Quaternary beach deposits in the circumpolar environmental zone (Table II). Late Quaternary marine deposits also occur in terrestrial 'oases' in East Antarctica (Korotkevich 1971, Pickard 1986, Hiller et al. 1988, Borman \& Fritzsche 1995) as well as on iceshelf surfaces in the Ross Sea (Baroni 1990, Kellogg et al. 1990). Marine fossils, which have been radiocarbon dated from these emerged deposits, provide a circumpolar framework for determining whether there have been synchronous environmental changes in Antarctic coastal areas during the Late Quaternary. Such circum-Antarctic environmental shifts may reveal past climate imprints and global feedbacks which have influenced the evolution of the Antarctic ice margin.

\section{Circum-Antarctic emerged marine deposits}

\section{Marine sediments}

Emerged marine sediments (which occur from the marine limit down to the present sea level) are influenced by the characteristics of the coastline as well as the prevailing environmental conditions. Around Antarctica, coastline types include bedrock coasts, ice-cliff coasts, ice-cored moraines and rocky/sandy coasts (Nichols 1968). The latter type includes alluvial areas with deltas, moraines, talus and elevated beach coastal plains. Development of these marine platforms occurs in embayments, regions with multi-year sea ice and

Table II. Circum-antarctic distribution of Late-Quaternary raised beach deposits from different coastal sectors of Antarctica.

\begin{tabular}{lccl}
\hline Location of raised beaches & Sector & No. of sites & Reference \\
\hline James Ross Island & $57-59^{\circ} \mathrm{W}$ & $4+$ & Ingólfsson et al. 1992, Hjort et al. 1997 \\
South Shetland Islands & $58-62^{\circ} \mathrm{W}$ & 83 & John \& Sugden 1971, Curl 1980, López-Martinez et al. 1992, 1996, Tatur et al. 1997 \\
Hope Bay & $63-64^{\circ} \mathrm{W}$ & 1 & Birkenmajer 1993 \\
Marguerite Bay & $66-70^{\circ} \mathrm{W}$ & 17 & Nichols 1960 \\
Alexander Island & $74-76^{\circ} \mathrm{W}$ & 1 & Sugden \& Clapperton 1980 \\
Ross Island & $166-168^{\circ} \mathrm{E}$ & 6 & Speden 1962 \\
Beaufort Island & $166-167^{\circ} \mathrm{E}$ & 3 & Stuiver et al. 1981, Kirk 1991 \\
Dailey Islands & $165-166^{\circ} \mathrm{E}$ & 1 & Kirk 1991 \\
Franklin Island & $168-169^{\circ} \mathrm{E}$ & 1 & Stuiver et al. 1981 \\
West McMurdo Sound & $163-164^{\circ} \mathrm{E}$ & 29 & Speden 1962, Nichols 1968, Stuiver et. al 1981. Kirk 1991 \\
Victoria Land Coast $\left(76-75^{\circ} \mathrm{S}\right)$ & $161-164^{\circ} \mathrm{E}$ & 13 & Kirk 1991 \\
Terra Nova Bay & $163-166^{\circ} \mathrm{E}$ & 19 & Orombelli et al. 1990, Baroni \& Orombelli 1989. 1991 \\
Capes Adare and Hallett & $170-172^{\circ} \mathrm{E}$ & 6 & Kirk 1991 \\
Scott Island & $179^{\circ} \mathrm{W}-180^{\circ} \mathrm{E}$ & 1 & Kirk 1991 \\
Windmill Islands & $110-111^{\circ} \mathrm{E}$ & 13 & Goodwin 1993 \\
Bunger Hills & $100-102^{\circ} \mathrm{E}$ & 12 & Adamson \& Colhoun 1992 \\
Gaussberg & $89-90^{\circ} \mathrm{E}$ & 2 & Zhivago \& Esteev 1970 \\
Rauer Islands & $77-78^{\circ} \mathrm{E}$ & 1 & Yevteyev 1962 \\
Vestfold Hills & $78-79^{\circ} \mathrm{E}$ & 16 & Pickard 1985 \\
Syowa coast & $38-40^{\circ} \mathrm{E}$ & 40 & Yoshida 1983, Hayashi \& Yoshida 1994, Maemoku et al. 1997 \\
Prince Olav Coast & $41-45^{\circ} \mathrm{E}$ & 5 & Yoshida 1983, Hayashi \& Yoshida 1994 \\
\hline
\end{tabular}

Areas of the emerged deposits range from tens of square metres to hectares. 
other sheltered areas, as well as in exposed coastal areas which are impacted to a greater extent by waves, wind and seasonal ice floes.

Permafrost, along with land and sea ice are specific to the polar regions in influencing the formation and preservation of emerged marine sedimentary deposits (Nichols 1961a, 1961b). These emerged beaches have ridges, swales, cusps, deltas and strandlines (Fig. 1). However, because of the strong influence of ice, many of the polar beaches become pitted over time and sometimes terminate abruptly because ice was present when they were formed. Polar beach ridges also can be influenced by 'ice push' or sediment deposition from stranded ice. Moreover, Antarctic coastal areas may be veneered by solifluction, fluvial and aeolian deposits.

Strandlines are particularly important because they provide time horizons that may be related to glacial isostatic and eustatic sea-level processes (Andrews 1970) as well as regional and local environmental conditions in Antarctic coastal areas. For example, in West McMurdo Sound, changes in the prevailing storm direction during the Late Quaternary are reflected by the relative orientations of proximal strandlines (Fig. 2a). Additional information about the relative magnitude

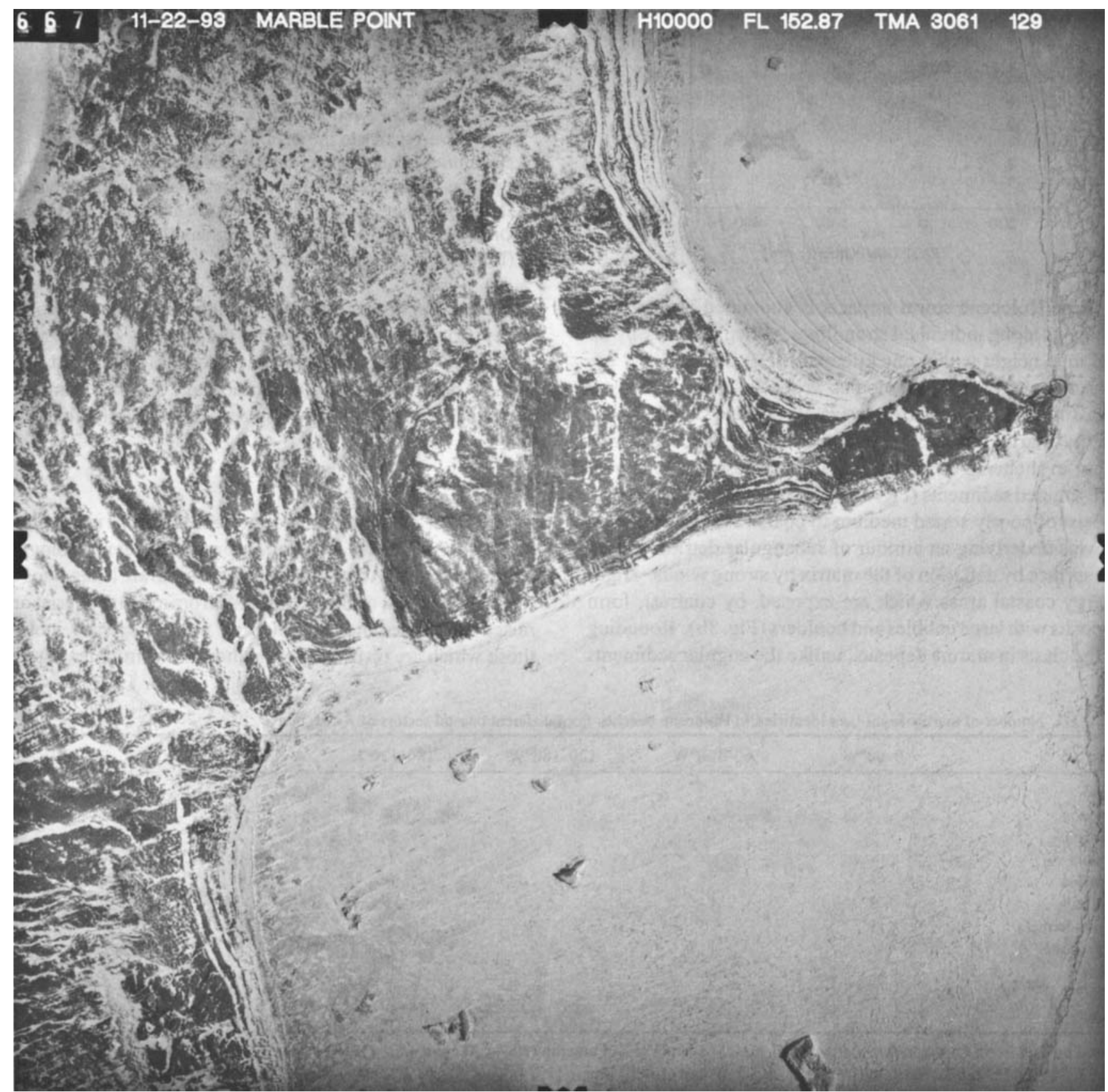

Fig. 1. Strandlines of emerged marine sedimentary deposits along Marble Point ( $\left.77^{\circ} 26^{\prime} \mathrm{S}, 163^{\circ} 153^{\prime} \mathrm{E}\right)$ in West McMurdo Sound, Antarctica. Orientations and elevations of individual strandlines as well as their rock deposits reflect relative sea-level changes and variable storm impacts. Photograph by the United States Geological Survey (TMA 3061) from an altitude of 10000 feet in 1993. 


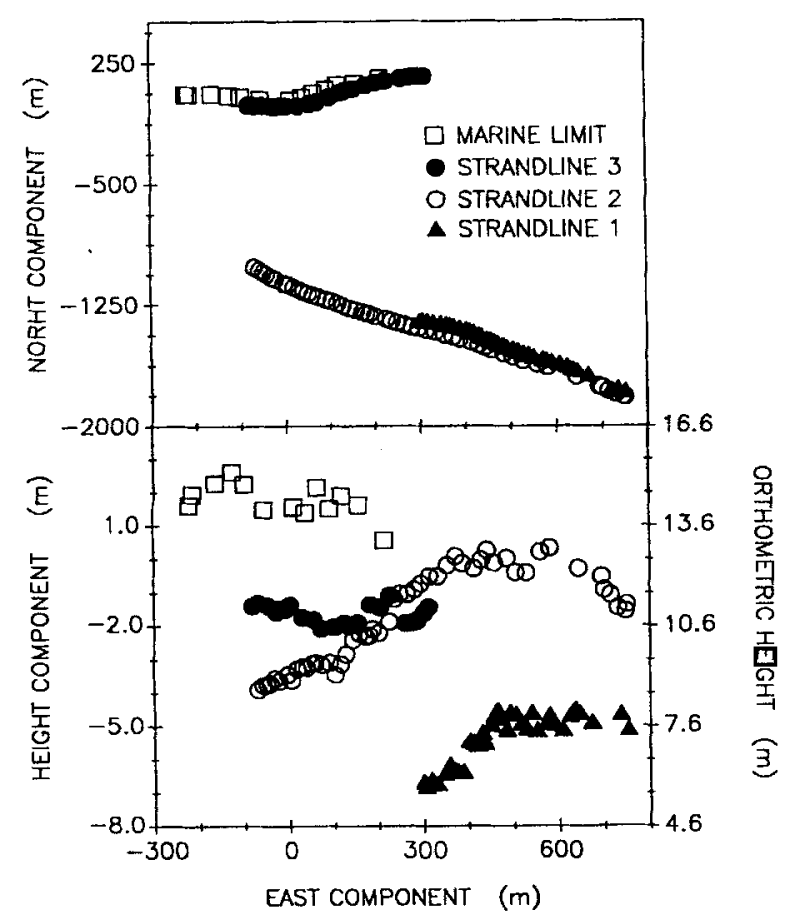

of these Holocene storm impacts is contained in elevation gradients along individual strandlines, which can vary by up to $4 \mathrm{~m}$ in height within one kilometre (Fig. 2b).

In a general sense, lithologies in these Antarctic coastal areas may be contrasted between 'low-energy' and 'highenergy' marine deposits. Low-energy marine deposits, which occur in sheltered coastal areas, are composed of relatively fine-grained sediments (Fig. 3a). Here, beach sediments may consist of poorly sorted medium to coarse sands and pebble gravels underlying an armour of subangular detritus left on the surface by deflation of the matrix by strong winds. Highenergy coastal areas which are exposed, by contrast, form deposits with large cobbles and boulders (Fig. 3b). Rounding of the clasts in marine deposits, unlike the angular sediments
Fig. 2. Holocene storm beach strandlines south of Marble Point, Antarctica, adjacent to dated $\left(6120-6430{ }^{14} \mathrm{C}\right.$ yr BP) macrofossil deposits (Stuiver et al. 1981). Elevations along the sea-level strandlines were measured with Global Positioning System (GPS) technology using dual-frequency Trimble 4000 SSE receivers. These kinematic surveys were conducted by walking along individual strandlines and then post-processing positions relative to the static site $\left(77^{\circ} 27^{\prime} 3.237^{\prime \prime} \mathrm{S}, 163^{\circ} 44^{\prime} 46.385^{\prime \prime} \mathrm{E}\right.$, $12.64 \mathrm{~m}$ a.s.1.) near South Stream (Berkman et al. 1998). a. GPS positions along the east and north axes of the strandlines relative to the static site showing changes in strandline orientation over time; b. GPS positions along the east and height axes of the strandlines relative to the static site showing changes in strandline elevation gradients over time. Orthometric heights represent elevations above sea level (Berkman et al. 1998).

which exist at higher elevations along rocky coasts, provide a key criterion for identifying the marine limits around Antarctica (Nichols 1968, Arche et al. 1996). Seaward of the marine limit, the Late Quaternary age of these emerged sediments can be confirmed by associated marine fossils.

\section{Marine fossils}

Species that are incorporated into emerged marine deposits come from different habitats and represent different ecological conditions in the Antarctic coastal zone: saline lakes, sites on top of ice shelves, ornithogenic soils from avian rookeries and raised beach sediments. Emerged marine species include those which are restricted to the marine environment during

Table III. Number of marine fossil taxa identified in Holocene beaches from different coastal sectors of Antarctica ${ }^{1.2}$

\begin{tabular}{|c|c|c|c|c|c|c|}
\hline Taxa & $0-60^{\circ} \mathrm{W}$ & $60-120^{\circ} \mathrm{W}$ & $120-180^{\circ} \mathrm{W}$ & $180-120^{\circ} \mathrm{E}$ & $120-60^{\circ} \mathrm{E}$ & $60-0^{\circ} \mathrm{E}$ \\
\hline Protozoa & & & & 14 & 18 & 22 \\
\hline Porifera & & & & 2 & 4 & \\
\hline Annelida & & & & 4 & 7 & 2 \\
\hline Mollusca & 3 & 1 & & 21 & 15 & 3 \\
\hline Echinodermata & 1 & & & 5 & & 1 \\
\hline Aves & 2 & & & 2 & 4 & 1 \\
\hline Mammalia & 3 & & & 3 & 4 & 2 \\
\hline
\end{tabular}

'Based on data from: Cameron \& Goldthwaite (1961), Speden (1962), Cameron (1964), Meguro et al. (1964), Nichols (1968), Shotton et al. (1969), John \& Sugden (1971), Korotkevich (1971), Webb \& Wrenn (1975), Omoto (1977), Curl (1980), Chapman-Smith (1981), Stuiver et al. (1981), Clapperton \& Sugden (1982), Adamson \& Pickard (1983), Yoshida (1983), Zhang \& Peterson (1984), Pickard (1985), Adamson \& Pickard (1986), Hiller et al. (1988), Baroni \& Orombelli (1989, 1991, 1994a), Adamson \& Colhoun (1992), Ryan et al. (1992), Ingolfsson et al. (1992), Goodwin (1993), Verkulich \& Hiller (1994), Emslie (1995), Hjort et al. (1997).

${ }^{2} \mathrm{Gaps}$ in the taxonomic data, to some extent, reflect an investigator bias rather than the absence of emerged fossils within coastal areas. 
their lifetime (such as marine flora, benthic invertebrates, fish and whales) as well as those which can move onto land independent of sea level (such as birds and seals).

Most of the Antarctic fossils deposits below the LatePleistocene/Holocene marine limit occur in low-energy coastal

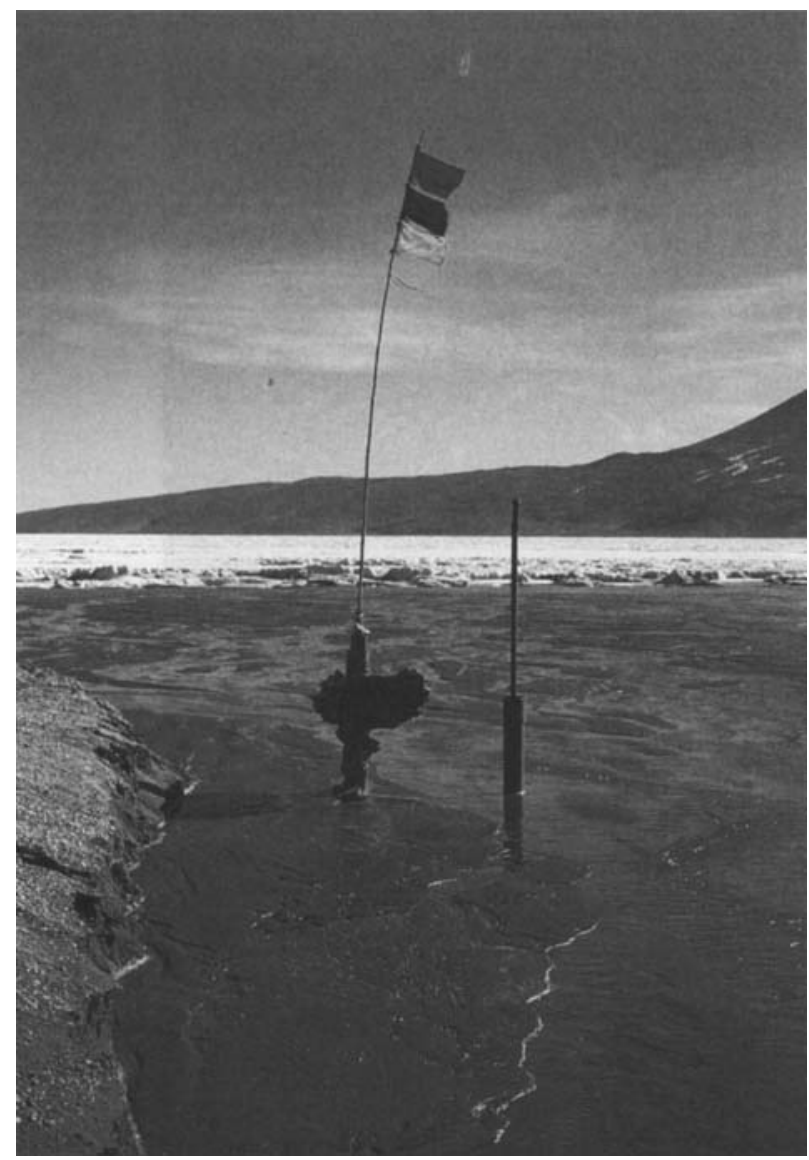

environments. These Late Quaternary species, which are distinct from Pliocene deposits that also occur in Antarctic coastal areas (Speden 1962, Chapman-Smith 1985, Pickard et al. 1988, Berkman \& Prentice 1996), have been identified from at least 150 different taxonomic groups (Table III: see Berkman 1994a for taxonomic list). The delineation of lakes in East Antarctica as former marine systems (Burton 1981) also has been confirmed by the observation of marine fossils such as molluscs, sponges, foraminifera, polychaetes and algae in emerged banks and sediment cores (Pickard 1985, Pickard et al. 1986, Fulford-Smith \& Sikes 1996, Melles et al. 1997). Emerged marine fossils have been found in all sectors of Antarctica except the region from $120^{\circ}$ to $180^{\circ} \mathrm{W}$ (Table III: Berkman 1997). Two of the most useful marine fossil groups for interpreting paleoenvironmental conditions in ice-free Antarctic coastal areas are calcareous invertebrate and avian assemblages.

The most abundant, widespread and best preserved emerged marine macrofossils around Antarctica are calcareous benthic invertebrates. The circumpolar scallop (Adamussium colbecki) and clam (Laternula elliptica) have been the among the most studied (Fig. 4a \& b) with more than 65 papers on the biochemistry, physiology, population biology, ecology and geology of these two species (review in Berkman in press).

In contrast, mobile marine species are not constrained by sea level and may be found far from the coast. For example, mummified crabeater seals (Lobodon carcinophagus) have been reported more than $50 \mathrm{~km}$ from the coastline at elevations above $1000 \mathrm{~m}$ (Péwé et al. 1959). Similarly, snow petrels (Pagodromoa nivea), have been found in rookeries over $300 \mathrm{~km}$ from the ocean (Hiller et al. 1988). The occupation of snow petrel and Adélie penguin rookeries (Pygoscelis adelie), however, are strongly influenced by their access to open water and provide proxies for interpreting past sea-ice

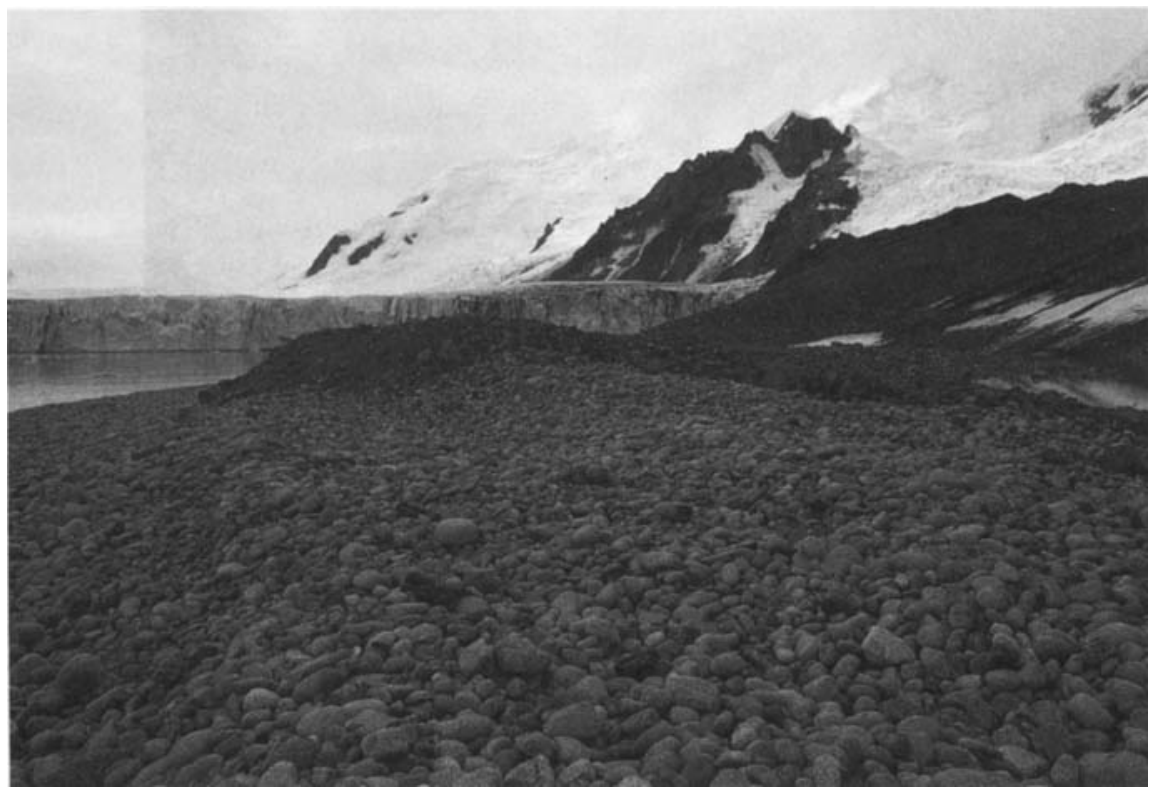

Fig. 3. a. Low-energy beach with sand deposits in Explorers Cove ( $78^{\circ} 38^{\prime} \mathrm{S}$, $166^{\circ} 25^{\prime} \mathrm{E}$ ), western McMurdo Sound. The Dry Valley Drilling Project (DVDP) core 8-10 at the mouth of Taylor Valley, shows recent glacial meltwater erosion of the Holocene delta which has been prograding into the marine environment. Photograph was taken by P.A. Berkman during the 1986-87 summer. b. Highenergy beach with cobble and boulder deposits along the coast of False Bay $\left(62^{\circ} 43^{\prime} \mathrm{S}, 60^{\circ} 22^{\prime} \mathrm{W}\right)$, Livingston Island. A push moraine from a recent glacial pulse is visible on the rounded beach deposits. Photograph was taken by J.López-Martinez during the 1993-94 summer. 

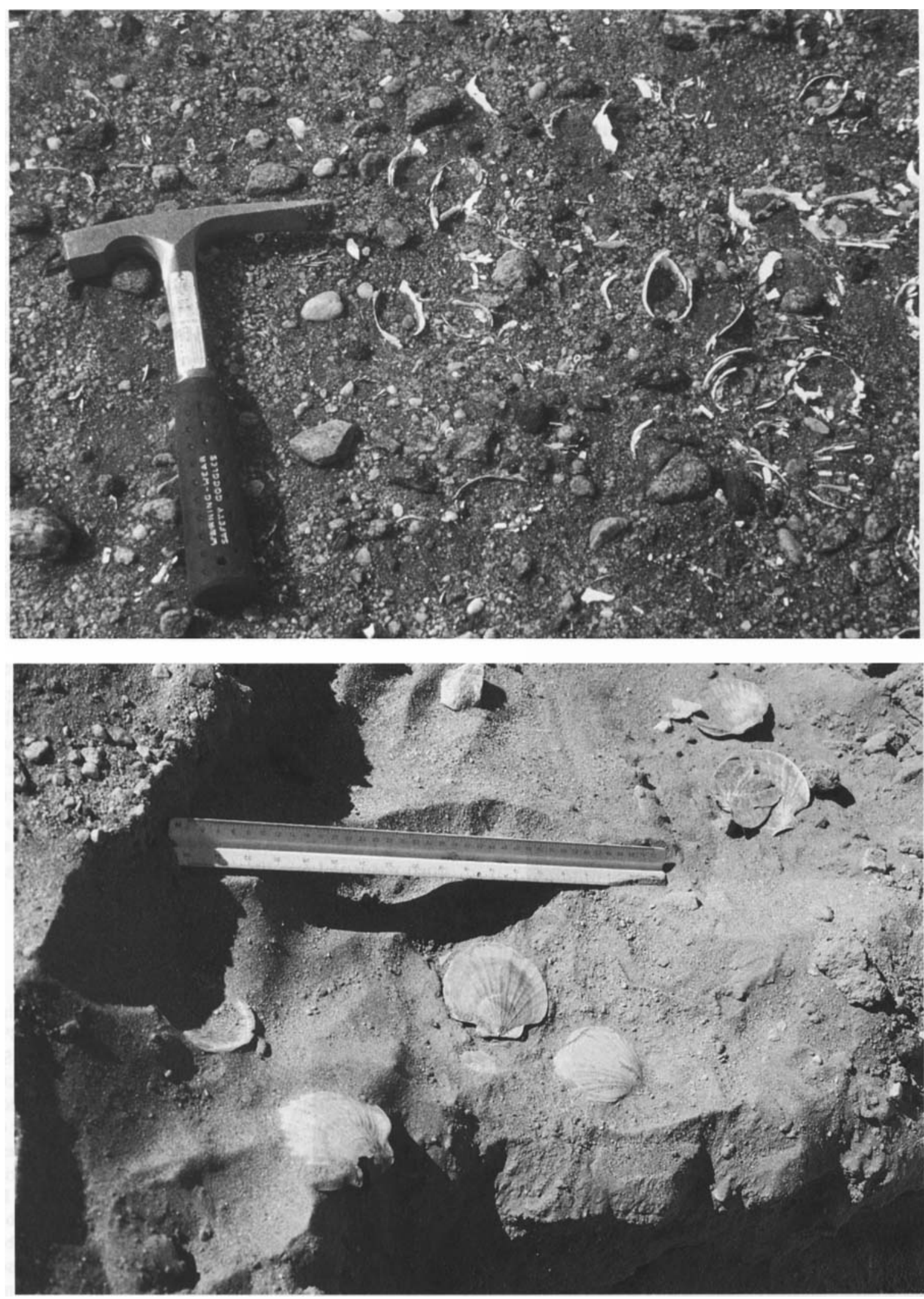

Fig. 4. Abundant in situ fossil deposits of a. the infaunal clam, Laternula elliptica, from a raised beach west of Lake Zakuro at Langhovde along the Syowa Coast in East Antarctica; b. the epifaunal scallop, Adamussium colbecki, from an emerged delta at South Stream in western McMurdo Sound. Both of these calcareous marine benthic invertebrates have circumpolar distributions as fossils in raised beaches and living assemblages in adjacent marine habitats (Berkman in press). The photographs were taken by M. Havashi and P.A. Berkman, respectively. 
coverage. Abandoned Adelie penguin rookeries have been identified along the Windmill Islands in East Antarctica (Goodwin 1993), along the coast of Victoria Land in the Ross Sea (Baroni \& Orombelli 1994a), and in the Antarctic Peninsula region (Tatur 1989, Emslie 1995, Tatur et al. 1997). Stomach oil deposits from snow petrel fossil breeding colonies also have been found in the Untersee Oasis (Hiller et al. 1988) and Bunger Hills (Verkulich \& Hiller 1994) of East Antarctica.

Beyond responding to sea level and ice sheet impacts over time, emerged fossils reflect the ambient environmental conditions that existed when the species were alive. Palaeoecological interpretations can be derived from the growth patterns and geochemistry of individual shells as well as the diversity, longevity, distribution, and abundances of entire assemblages. Modern analogues, which commonly live in adjacent marine environments around the continent, provide experimental baselines for assessing past environmental conditions (Berkman 1997).

\section{Radiocarbon dating in the Antarctic marine ecosystem}

Ultimately, the value of any paleoenvironmental proxy is constrained by its dating and the accuracy with which it can be placed in an historical context. The most reliable chronologies are derived from sedimentary, glacial and biogenic deposits which continuously accumulate over known time intervals. The principal age control for Late Quaternary events is derived from the radioactive decay of ${ }^{14} \mathrm{C}$ to stable ${ }^{12} \mathrm{C}$ (conventional half-life is $5568 \mathrm{yrs}$ ). With the advent of accelerator mass spectrometry (which requires less than a milligram of carbon as opposed to several grams for

Table IV. Reservoir corrections which have been proposed for radiocarbon dating biotic deposits from the Southern Ocean.

\begin{tabular}{|c|c|c|c|c|}
\hline $\begin{array}{l}\text { radiocarbon } \\
\text { reservoir } \\
\text { correction } \\
\text { (yrs) } \\
\end{array}$ & $\begin{array}{l}\text { sample collection } \\
\text { location }\end{array}$ & $\begin{array}{l}\text { reservoir correction } \\
\text { derivation' }\end{array}$ & $\begin{array}{l}\text { reservoir correction } \\
\text { application }\end{array}$ & Reference \\
\hline $\begin{array}{l}750 \\
800-3000\end{array}$ & $\begin{array}{l}\text { Antarctic Peninsula } \\
\text { Syowa coast }\end{array}$ & $\begin{array}{l}\text { post-bomb shells } \\
\text { post-bomb seawater and various } \\
\text { marine species }\end{array}$ & $\begin{array}{l}\text { Antarctic Peninsula, general } \\
\text { general }\end{array}$ & $\begin{array}{l}\text { Sugden \& John } 1973 \\
\text { Omoto } 1983\end{array}$ \\
\hline $850 \pm 300$ & Weddell Sea & post-bomb penguins and marine algae & $10^{\circ} \mathrm{W}$ to $40^{\circ} \mathrm{E}$, general & Hiller et al. 1988 \\
\hline 850 & South Shetland Islands & $\begin{array}{l}\text { pre-bomb and post-bomb whale and } \\
\text { seal bones }\end{array}$ & $\begin{array}{l}\text { whales and seals, } \\
\text { South Shetland Islands }\end{array}$ & Clapperton \& Sugden 1988 \\
\hline $850-1450$ & McMurdo Sound & post-bomb molluscs & general & Stuiver et al. 1976 \\
\hline 940 & Antarctic Peninsula & pre-bomb and post-bomb seals and whales & general & Curl 1980 \\
\hline$>1000$ & Bunger Hills & marine sediments & marine sediments & Melles et al. 1994 \\
\hline$>1000$ & Antarctic Peninsula & pre-bomb whalebones & whalebones & Gordon \& Harkness 1992 \\
\hline $1065-1760$ & Ross Sea & pre-bomb penguins and seals & penguins and seals & Mabin 1985,1986 \\
\hline 1090 & Ross Sea & post-bomb penguins & penguins & Whitehouse 1988, Goodwin 1993 \\
\hline 1100 & Syowa coast & post-bomb marine organisms $\&$ seawater & marine organisms, Syowa coast & Hayashi \& Yoshida 1994 \\
\hline 1120 & Syowa coast & post-bomb marine organisms & general & $\begin{array}{l}\text { Yoshida \& Moriwaki 1979, } \\
\text { Yoshida } 1983\end{array}$ \\
\hline 1130 & circumpolar & pre-bomb and post-bomb penguins & penguins & Berkman 1997 \\
\hline 1200 & McMurdo Sound & post-bomb seal & general & Olsen \& Broecker 1961 \\
\hline 1200 & Antarctic Peninsula & post-bomb calcareous marine species & Antarctic Peninsula & Domack 1992 \\
\hline $1200-1300$ & Hope Bay & pre-bomb penguins & $\begin{array}{l}\text { marine organisms, } \\
\text { Antarctic Peninsula }\end{array}$ & Bjorck et al. 1991 \\
\hline $1250-1300$ & Antarctic Peninsula & $\begin{array}{l}\text { various pre-bomb and post-bomb } \\
\text { marine species }\end{array}$ & Antarctic Peninsula & Gordon \& Harkness 1992 \\
\hline 1300 & Victoria Land coast & pre-bomb seal and penguin & general & Stuiver \& Braziunas 1985 \\
\hline 1300 & Vestfold Hills & post-bomb molluscs \& marine sediment & general & Adamson \& Pickard 1986 \\
\hline 1300 & East Antarctica & various post-bomb marine species & East Antarctica & Verkulich \& Hiller 1994 \\
\hline 1300 & circumpolar & $\begin{array}{l}\text { pre-bomb and post-bomb calcareous } \\
\text { marine species }\end{array}$ & calcareous marine species & Berkman \& Forman 1996 \\
\hline 1400 & circumpolar & pre-bomb and post-bomb molluscs & molluscs & Berkman 1994a \\
\hline 1400 & circumpolar & $\begin{array}{l}\text { various pre-bomb and post-bomb } \\
\text { marine species }\end{array}$ & shells, seals and penguins & Gordon \& Harkness 1992 \\
\hline 1424 & circumpolar & pre-bomb and post-bomb seals & seals & Berkman 1997 \\
\hline 1700 & Wilkes Land coast & marine algae & $\begin{array}{l}\text { sediment cores along } \\
\text { Wilkes Land coast }\end{array}$ & Domack et al. 1991 \\
\hline 5000 & Wilkes Land coast & foraminifera & $\begin{array}{l}\text { sediment cores along } \\
\text { Wilkes Land coast }\end{array}$ & Domack et al. 1991 \\
\hline $5020-5500$ & Wilkes Land coast & $\begin{array}{l}\text { post-bomb sedimentary calcite and } \\
\text { organic carbon }\end{array}$ & $\begin{array}{l}\text { sediment cores along } \\
\text { Wilkes Land coast }\end{array}$ & Domack ef al. 1989 \\
\hline
\end{tabular}

${ }^{1}$ Pre-bomb and post-bomb time periods are relative to calendar year 1950. 
conventional dating), radiocarbon dating can be used for effectively determining the ages of organic materials that have lived during the last 45000 yrs (Geyh \& Schleicher 1990, Kitagawa \& van der Plicht 1998). However, the accuracy of radiocarbon age determinations beyond 35000 yars is questionable because of contamination and

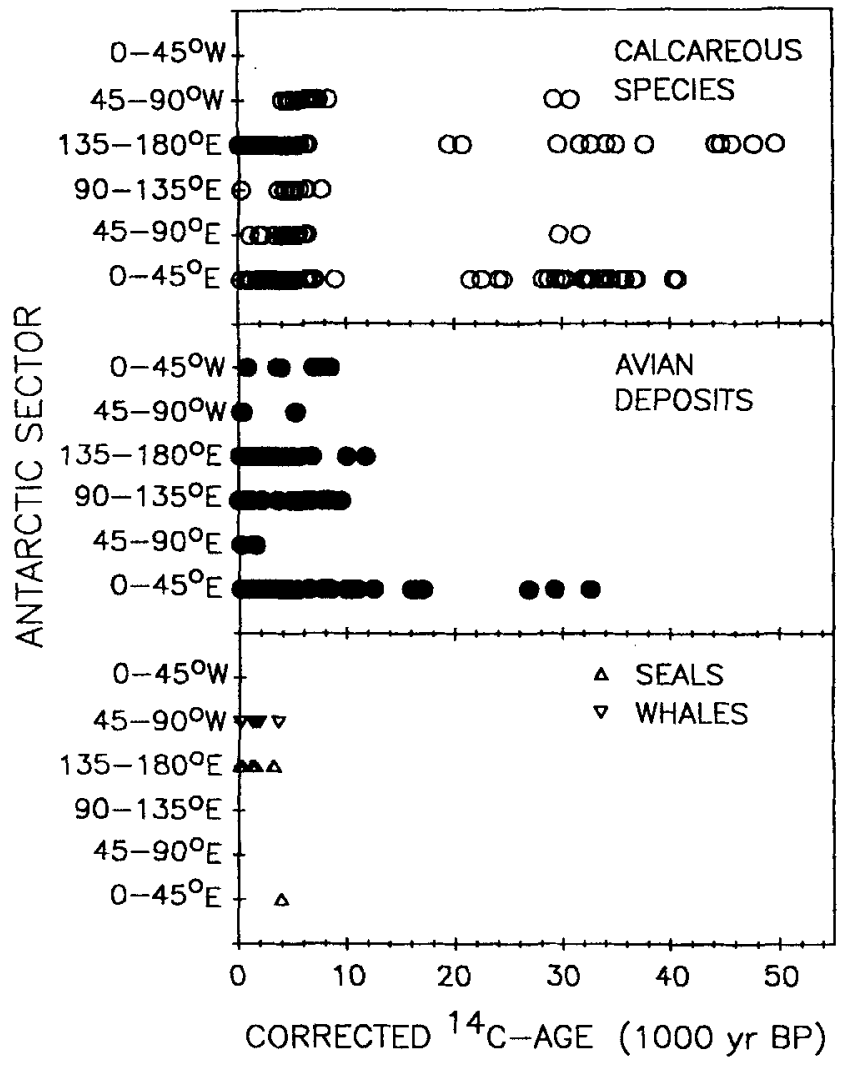

Fig. 5. Radiocarbon-dated emerged marine fossil deposits (calacareous marine species, primarily mollusc shells; avian deposits; and whale and seal deposits) from the Late Quaternary around Antarctica. The data are presented in relation to different Antarctic coastal sectors: $\mathbf{0}-\mathbf{4 5}^{\circ} \mathbf{E}$ (Meguro et al. 1964, Yoshida 1970, 1973, 1983, Moriwaki 1974, 1976. Omoto et al. 1974, Omoto 1976, 1977, 1978, Nogami 1977, Hiller et al. 1988, Hayashi \& Yoshida 1994, Igarashi et al. 1995); 45-90 ${ }^{\circ} \mathrm{E}$ (Adamson \& Pickard 1983, Zhang et al. 1983, Pickard \& Adamson 1983a, 1983b, Pickard \& Seppelt 1984, Pickard 1985, Zhang \& Peterson 1984, Hiller et al. 1988); 90-135 E (Cameron \& Goldthwait 1961, Adamson \& Colhoun 1992, Verkulich \& Hiller 1994, Melles et al. 1997);

135-180 ${ }^{\circ} \mathbf{E}$ (Péwé et al. 1959, Olsen \& Broecker 1961, Nichols 1968, Hendy et al. 1969, Stuiver et al. 1976, 1981, Speir \& Cowling 1984, Whitehouse et al. 1988, Kellogg et al. 1990, Baroni et al. 1991, Baroni \& Orombelli 1994a, 1994b, Hall 1997); 0-45 ${ }^{\circ} \mathrm{W}$ (Hiller et al. 1988, Lintinen \& Nenonen 1997); 45-90 ${ }^{\circ} \mathrm{W}$ (Shotton et al. 1968, 1969, Sugden \& John 1973, Hansom 1979, Curl 1980, Sugden \& Clapperton 1980, Rabassa 1983, Barsch \& Maubacher 1986, Ingólfsson et al. 1992. Hjort et al. 1997, Tatur et al. 1997). All of the radiocarbon dates have been corrected by subtracting the 1300-yr age of the prebomb Antarctic marine radiocarbon reservoir (see text). other factors when there is less than $1 \%$ of the original ${ }^{14} \mathrm{C}$ remaining.

The validity of Late Pleistocene radiocarbon ages can be assessed by measuring the ratios of amino acids which convert from the L-configuration when an animal is living to the Dconfiguration after it dies (Wehmiller 1982, Miller \& BrighamGrette 1989). For example, previous measurements (Clapperton \& Sugden 1982, Hansom \& Flint 1989, Ingólfsson et al. 1992, Martinez-Macchiavello et al. 1996) show that there is a direct relationship between the $\mathrm{D} / \mathrm{L}$ ratios and radiocarbon ages of calcareous marine organisms in the Antarctic Peninsula region: recent molluscs (zero age) had D/ $\mathrm{L}$ ratios of $0.011 \pm 0.002 ; 6865 \pm 957{ }^{14} \mathrm{C}$ yr BP (uncorrected radiocarbon years before present) barnacles and molluscs had $\mathrm{D} / \mathrm{L}$ ratios of $0.016 \pm 0.006$; and $35025 \pm 704{ }^{14} \mathrm{C}$ yr BP molluscs had $D / L$ ratios of $0.048 \pm 0.035$. In other analyses, however, Antarctic mollusc shells with ages of 30600 and $32160{ }^{14} \mathrm{C}$ yr BP have been measured with $\mathrm{D} / \mathrm{L}$ ratios ranging from 0.113 to 0.169 that indicate they were at least 120000 yrs old (Clapperton \& Sugden 1982). These data indicate that Late Pleistocene radiocarbon ages for Antarctic marine fossils should be considered as minimum ages and that their true ages may be much older.

Beyond the technical considerations, radiocarbon ages of Antarctic marine species are strongly influenced by the local seawater reservoir age. In the Southern Ocean, the radiocarbon reservoir is dominated by the upwelling of deep water at the Antarctic Divergence and produces apparent radiocarbon ages of marine species that exceed 1000 years (Broecker 1963, Stuiver et al. 1983, Gordon \& Harkness 1992, Berkman \& Forman 1996). The radiocarbon reservoir in the Southern Ocean also has been affected by natural changes in the production of atmospheric radiocarbon (Bard et al. 1990, Stuiver \& Braziunas 1993). Additionally, spatial variability in the Antarctic marine radiocarbon reservoir (Omoto 1983, Gordon \& Harkness 1992) may be influenced by glacial meltwater (Domack et al. 1989, Melles et al. 1994) or regional differences in upwelling around the continent.

Aside from natural impacts, human activities also have dramatically altered the Southern Ocean radiocarbon reservoir. During the 20th century, "old" radiocarbon from fossil fuel combustion (Suess 1955, Stuiver \& Quay 1981) and "new" radiocarbon from nuclear explosions (Broecker \& Walton 1959) have been added to the global atmosphere. The 53\% difference between the mean $\Delta^{14} \mathrm{C}$ values of the pre-bomb and post-bomb biogenic carbonates (Berkman \& Forman 1996) is in close agreement with the $c .50 \%$ offset which has been described for surface seawater south of $50^{\circ} \mathrm{S}$ (Broecker et al. 1985). Moreover, the bomb signal is evident in long-lived brachiopods which were collected alive near Signy Island (Peck \& Brey 1996). Together, these radiocarbon data indicate that the surface seawater age of the Antarctic marine radiocarbon reservoir has been altered by more than 500 years during the 20th century due to nuclear explosions and fossil fuel combustion. More importantly, prior to 1950 the 
radiocarbon content of surface waters around Antarctica was nearly equivalent to the 1300 -yr age of the deep waters which are upwelling around Antarctica today (Michel \& Druffel 1983, Stuiver et al. 1983). These geochemical data indicate that, as a first approximation, the general radiocarbon reservoir correction for the circum-Antarctic marine ecosystem is 1300 years (Berkman \& Forman 1996).

In addition to the marine reservoir effects, radiocarbon ages of Southern Ocean species are influenced by 'vital effects' associated with their ecology and composition. For example, based on published data (Gordon \& Harkness 1992, Berkman \& Forman 1996), there are significant differences in the "prebomb" radiocarbon ages of living calcareous invertebrates $(1346 \pm 104 \mathrm{yrs})$, penguins $(1130 \pm 134 \mathrm{yrs})$ and seals $(1424 \pm 200$ yrs). Radiocarbon ages of these taxa were similarly offset after the Earth's atmosphere was contaminated by bomb-produced radiocarbon: calcareous invertebrates $(901 \pm 227 \mathrm{yrs})$, penguins $(606 \pm 388 \mathrm{yrs})$ and seals (778 \pm 412 yrs). Inherent differences between Antarctic marine taxa also are reflected by their $\delta^{13} \mathrm{C}$ values (Harkness 1979 , Gordon \& Harkness 1992) relative to seawater which is around $0 \%$ : carbonate species $(1.6 \pm 0.6 \%)$, algae $(-18.7 \pm 6.2 \%)$, seals and whales $(-19.3 \pm 2.4 \%)$, penguins $(-20.0 \pm 3.1 \%)$ as well as krill and fish $(-26.3 \pm 4.8 \%)$.

Marine sediments present additional problems for interpreting radiocarbon ages because of mixtures of organic constituents that may differ in age by as much as $10000 \mathrm{yrs}$ (Eglinton et al. 1997). In the Southern Ocean, radiocarbondated sedimentary organic matter and calcite are offset in age on the order of 700 to 3000 yrs (Domack et al. 1995). In East Antarctica, this radiocarbon dating problem with bulk sediments (which may range up to 7000 yrs between samples) has been attributed to contamination from Jurassic pollen, spores and other materials which have been eroded and incorporated into Holocene diatom oozes (Harris et al. 1996). Moreover, because of varying degrees of meltwater dilution over time, radiocarbon ages of bulk organic carbon are irregularly distributed in emerged marine sedimentary sequences (Melles et al. 1994, 1997).

The above data indicate that geochemical, glaciological and ecological as well as technical considerations are necessary for interpreting radiocarbon ages within the global climate system (Stuiver \& Reimer 1993, Stuiver \& Braziunas 1993, Hughen et al. 1998). For Antarctic marine fossils, these diverse considerations have confused the situation with more than 25 proposed radiocarbon reservoir corrections which range from 750 to $5500 \mathrm{yrs}$ (Table IV). Because accepted species-specific and region-specific corrections have not yet been developed, the general pre-bomb marine reservoir correction of 1300 years will be applied to the radiocarbon ages of emerged Antarctic marine fossils discussed in this paper.

The composite radiocarbon age profile of emerged Late Quaternary fossils in the circum-Antarctic coastal zone(Fig. 5), shows a bimodal distribution (Kellogg et al. 1990, Igarashi et al. 1995). The same bimodal age distribution has also been observed from marine-lacustrine sedimentary sequences cored in the Bunger Hills in East Antarctica (Melles et al. 1997). Clearly, there was a distinct environmental phase during the Holocene when diverse species assemblages (ranging from calcareous marine taxa to birds, seals and whales) were occupying the circumpolar coastal zone. There also appears to have been an earlier phase of coastal occupation by calcareous marine species and birds which occurred between at least 35000 and $20000 \mathrm{yr} \mathrm{BP}$. These emerged marine deposits provide a circumpolar framework for interpreting environmental shifts in Antarctic coastal regions in relation to global climate changes during the Late Quaternary.

\section{Circum-Antarctic emerged marine chronologies for the Late Quaternary}

Antarctic ice margin evolution during the Late Pleistocene

The data in Fig. 2 show that calcareous marine fossils with continuous radiocarbon-age distributions between at least 35000 and $20000 \mathrm{yr}$ BP also have been found along the Syowa coast (Yoshida 1983, Hayashi \& Yoshida 1994, Igarashi et al. 1995) as well as on the McMurdo Ice Shelf (Kellogg et al. 1990). Isolated deposits of reworked biogenic carbonates with radiocarbon ages from this period also have been found along the coasts of east and west McMurdo Sound (Hendy et al. 1969, Hall 1997), the Antarctic Peninsula (Sugden \& Clapperton 1980, Ingólfsson et al. 1992) and Wilkes Land (Zhang \& Peterson 1985). In some cases, radiocarbon ages from these isolated deposits greatly underestimate the actual fossil ages, as shown by Clapperton \& Sugden (1982), and by Pickard (1986) who noted that Pliocene molluscs from Marine Plain were being misinterpreted as Late Pleistocene in age. Nonetheless, the complete absence of any carbonate fossils in Antarctic coastal areas from roughly 20000 to $8500 \mathrm{yr} \mathrm{BP}$ (Fig. 5), which is well with the resolution of radiocarbon dating, indicates that calcareous species were not inhabiting nearshore marine environments around the continent during much of the LGM and for several thousand years afterwards.

Aside from the fact that some of the Late Pleistocene radiocarbon ages of calcareous marine macrofossils in Fig. 2 may be much older, the presence of marine species in Antarctic coastal areas between at least 35000 and $20000 \mathrm{yr}$ BP is consistent with the relatively warm climate conditions of Marine Isotope Stage 3 (MIS3), approximately 61000 to $29000 \mathrm{yr} \mathrm{BP}$, which has been identified in marine sediment cores from the southern Indian Ocean (Hays et al. 1976) as well as in ice cores from Antarctica, Greenland and the Tibetan Plateau (Jouzel et al. 1987, 1989, Thompson et al. 1997).

Based on marine sediment core data from the Southern Ocean, it has been shown that there was a 'melt-water lid' covering the ocean south of the Antarctic Convergence from 35000 to 17000 yr вp (Labeyrie et al. 1986). This marked 


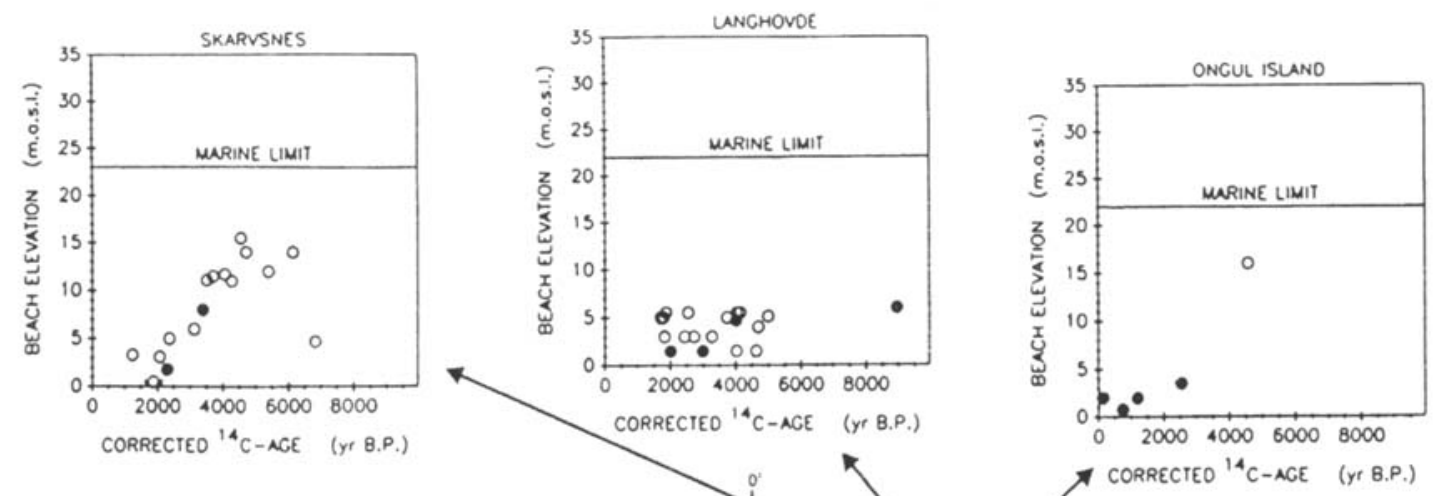



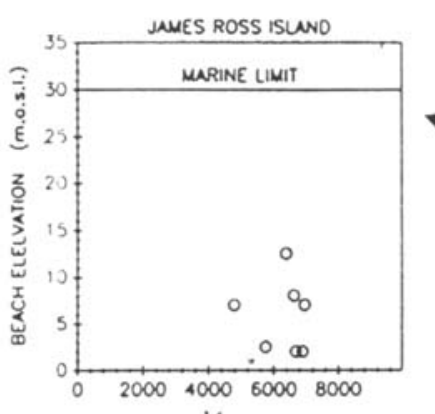

CORRECTED ${ }^{14} \mathrm{C}$-AGE $\quad$ (Yr B.P.)
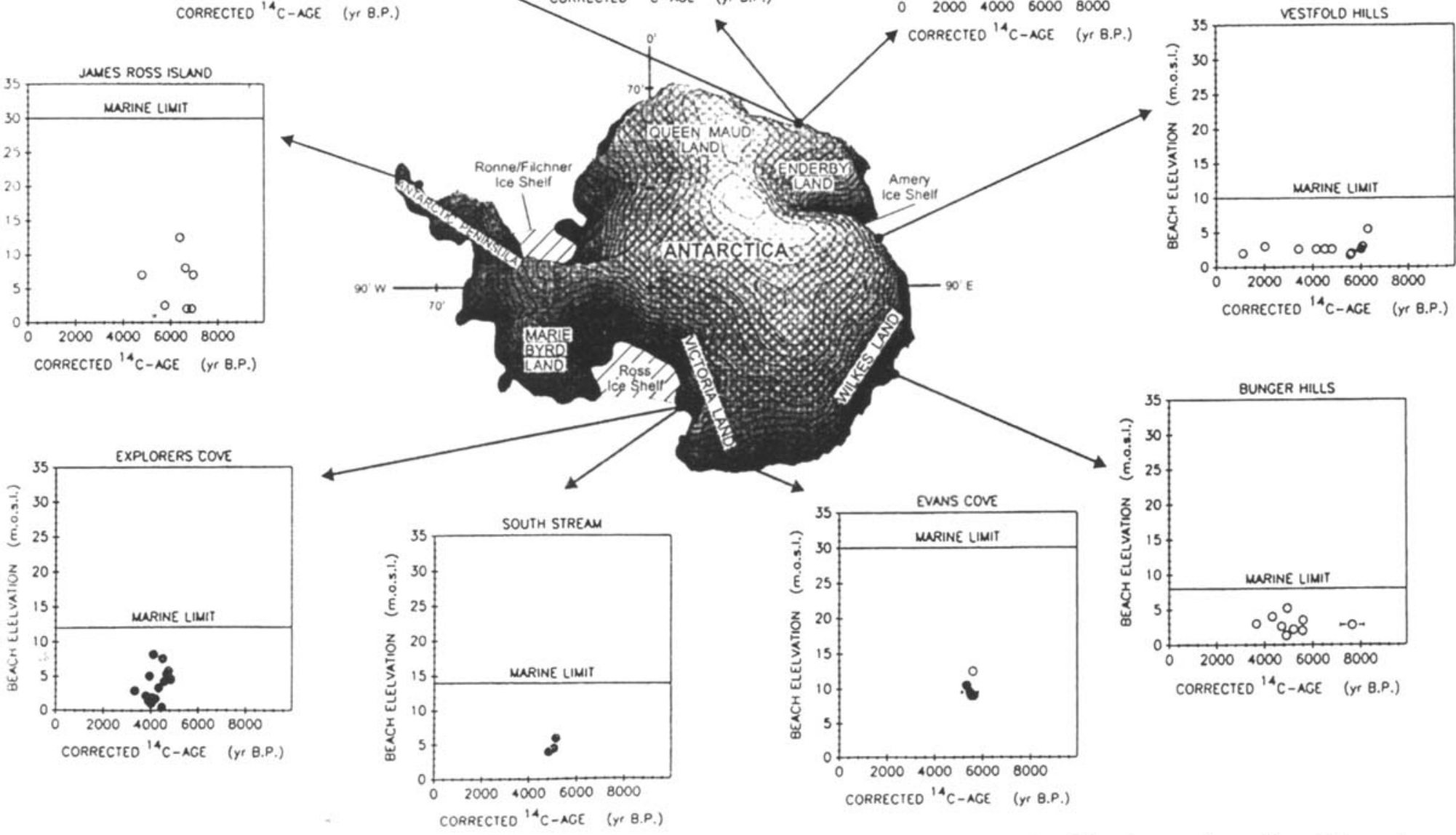

CORRECTEO ${ }^{14} \mathrm{C}$ - AGE (yr B.P.)

BUNGER HILLS

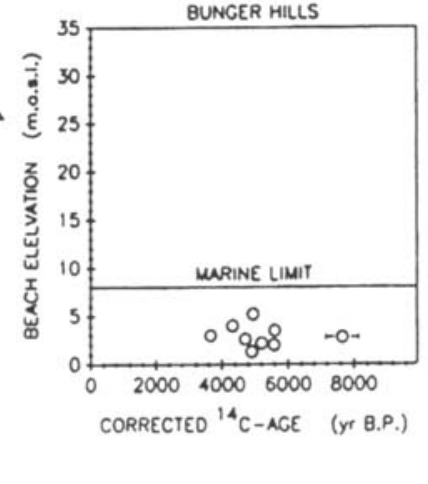

Fig. 6. Elevation-age relationships relative to the marine limits for raised beaches in East and West Antarctica based on deposits of the circumpolar scallop (Adamussium colbecki: ), and clam (Laternula elliptica: O). Radiocarbon ages of these calcareous benthic macroinvertebrates have been corrected by subtracting the 1300 -yr age of Southern Ocean seawater (see text). Data were compiled from: Explorers Cove (Stuiver et al. 1981); South Stream (Stuiver et al. 1981); Terra Nova Bay (Baroni \& Orombelli 1991);

Yoshida 1994); and James Ross Island (Hjort et al. 1997). Three-dimensional illustration of Antarctica based on data from Drewry (1983). 
change in the hydrology of the Southern Ocean, which was caused by abundant melting icebergs calved from surging glaciers and ice shelves around Antarctica (Labeyrie et al. 1986), led to surface-water stratification and subsequent reduction in atmospheric $\mathrm{CO}_{2}$ concentrations during the last glacial period (Francois et al. 1997). The Dome C, Vostok and Byrd ice-core records further reveal that the Last Glacial Maximum (LGM) occurred around Antarctica from 25000 to $15000 \mathrm{yr}$ BP (Jouzel et al. 1989).

The transition from interstadial to glacial conditions is reflected in Antarctic coastal areas. Radiocarbon-dated marine sediments from the western Ross Sea $\left(c .165-175^{\circ} \mathrm{E}\right)$ indicate that there was open water on the outer continental shelf near north Victoria Land from 32685 to $18200{ }^{14} \mathrm{C}$ yr BP, followed by a hiatus of 6000 years when the basin was covered by an extended ice shelf (Licht et al. 1996). Geological data from the Dry Valleys in southern Victoria Land also suggest that ice streams from West Antarctica extended across McMurdo Sound from 23800 to $13800{ }^{14} \mathrm{C} \mathrm{yr} \mathrm{BP}$ (Stuiver et al. 1981, Denton et al. 1989, Hall 1997). Similarly, radiocarbon dating of lacustrine sediments from the Bunger Hills in East Antarctica show MIS3 ages ranging from 35700 to $24140{ }^{14} \mathrm{C}$ yr BP which were followed by a hiatus in deposition until $14320{ }^{14} \mathrm{C}$ yr BP (Melles et al. 1997). Additional geomorphological evidence from the Windmill Islands (c. $\left.110^{\circ} \mathrm{E}\right)$, Bunger Hills $\left(c .101^{\circ} \mathrm{E}\right)$ and Vestfold Hills $\left(c .78^{\circ} \mathrm{E}\right)$ suggests that the East Antarctic Ice Sheet only expanded to a limited extent across the coast of Wilkes Land during the LGM (Colhoun et al. 1992, Goodwin 1993, Colhoun 1997).

In contrast, evidence from moss deposits suggests that the Larsemann Hills $\left(76^{\circ} \mathrm{E}\right)$ were deglaciated by $24950{ }^{14} \mathrm{C}$ yr BP (Burgess et al. 1994). Geomorphological evidence also suggests that the Syowa coast $\left(\right.$ c. $\left.39^{\circ} \mathrm{E}\right)$ remained unglaciated throughout this period (Omoto 1977, Hayashi \& Yoshida 1994). In addition, stomach oil deposits from breeding colonies of petrel species in the Untersee Oasis $\left(13^{\circ} \mathrm{E}\right)$ have radiocarbon ages that are continuously distributed from $33900{ }^{14} \mathrm{C}$ yr Bp to the present, suggesting that this region of East Antarctica has been continuously ice free since MIS3 (Hiller et al. 1988).

Based on glacial drift and emerged beach deposits, LatePleistocene/Holocene deglaciation in the Ross Sea region of Antarctica is thought to have begun around $13000 \mathrm{yr} \mathrm{BP}$ and continued until the mid-Holocene (Denton et al. 1989). Recent radiocarbon ages of algae in kenyte deposits from the McMurdo Dry Valleys (Hall 1997) and cosmogenic exposure ages of subglacial erratics from the Vestfold Hills (Fabel et al. 1997) support this timing of deglacial onset. The timing of Antarctic deglaciation also has been deduced from geophysical models of ice-sheet topographic changes (Clark \& Lingle 1979, Nakada \& Lambeck 1988, Peltier 1994), which have been constructed to explain the history of sea-level rise since the LGM (Fairbanks 1989). The magnitude of the Antarctic contribution to sea-level rise after the retreat of the northern hemisphere ice sheets, however, is unresolved (Colhoun et al.

\section{DVDP 8-10}

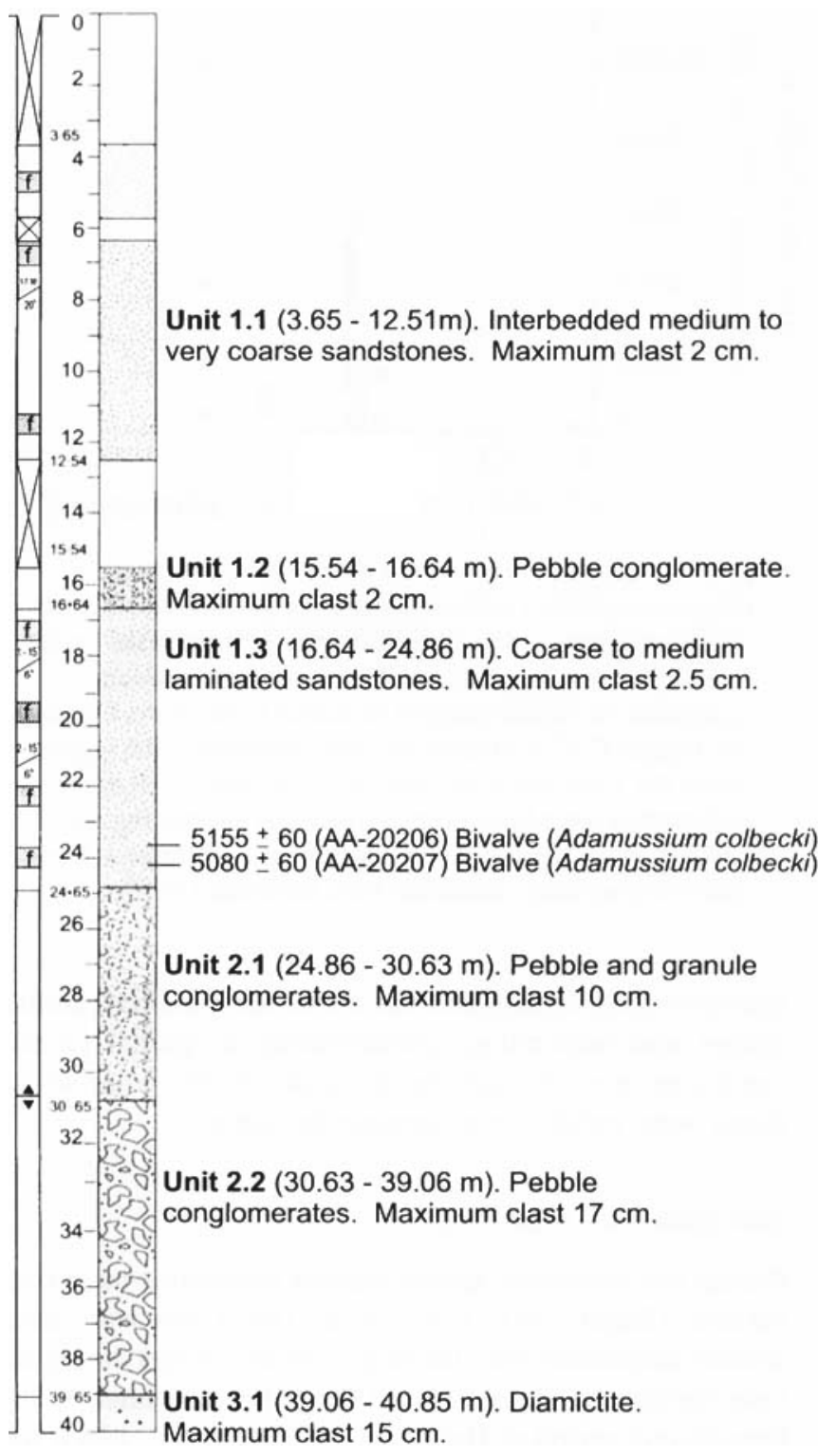

Fig. 7. Stratigraphy of the core DVDP 8-10 in Explorers Cove (Fig. 3a) based on the profile by McKelvey (1981). New radiocarbon ages (with associated laboratory numbers from the University of Arizona) are shown for calcareous macrofossils from the core. An earlier radiocarbon date at a core depth of 23 to $24 \mathrm{~m}$ was $6670 \pm 200{ }^{14} \mathrm{C}$ yr BP (Stuiver et al. 1976).

1992).

Together, these diverse datasets indicate that the cycle of colonization, absence and recolonization by nearshore marine species around Antarctica (Fig. 5) coincided with global climate changes during Marine Isotope Stage 3, the Last Glacial Maximum and the subsequent Holocene interglacial period. Moreover, the uniform absence of calcareous marine macrofossils around Antarctica, from roughly 20000 to 


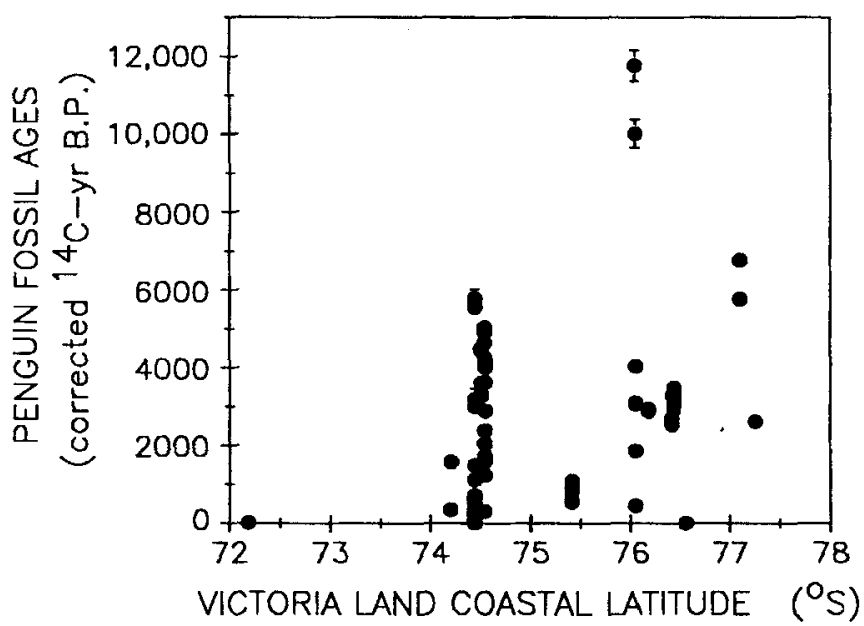

Fig. 8. Locations of radiocarbon-dated Adélie penguin (Pygoscelis adelie) rookeries along the Victoria Land coast which have been redrawn in relation to latitude based on data from Baroni \& Orombelli (1994a). Note the continuous occupation of Adélie penguin rookeries north of the Drygalski Ice 'Tongue $\left(75^{\circ} 24^{\prime} \mathrm{S}\right)$ since the mid-Holocene in the region where the Terra Nova Bay polyna exists today. All of the radiocarbon dates have been corrected by subtracting the 1300-yr age of the pre-bomb Antarctic marine radiocarbon reservoir (see text). Modified from Berkman (1997).

$8500 \mathrm{yr} \mathrm{BP}$ (Fig. 5), suggests that the circum-Antarctic coastal system was responding synchronously to glacial climate conditions, even though the dynamics of the adjacent ice sheets were variable in a circumpolar context.

\section{Mid-Holocene climate shift}

During the Holocene, global climate conditions have been variable (Beget 1983, Alley et al. 1997), but with much smaller amplitudes than the huge climate swings during the Late Pleistocene (Taylor et al. 1993, Behl \& Kennett 1996). One distinct period of Holocene climate change, which was sustained for more than three millennia, occurred during the mid-Holocene when global average temperatures were at their maximum (Folland et al. 1990, Pielou 1991). Antarctic ice-core records indicate, however, that this Holocene 'climate optimum' occurred earlier in the Southern Hemisphere than in the Northern Hemisphere and that a significant cooling period occurred around Antarctica from 8000 to $4000 \mathrm{yr}$ BP (Lorius et al. 1979, Cias et al. 1992). These data suggest that hemispheric temperatures were not in phase on a global scale during the early-mid Holocene. However, if the mid-Holocene 'climate optimum' represents a global change, then there should have been an Antarctic response, although perhaps not in terms of temperature. Cryospheric changes in the circumAntarctic coastal zone provide a framework for assessing climate feedbacks associated with the global hydrological cycle (Chahine 1992, Jacobs 1992) during the Holocene.
In contrast to the fragments of calcareous marine macrofossils from MIS3 (Fig. 5), Holocene macrofossils have been found intact and in growth positions within emerged beaches around Antarctica (Berkman 1992, 1994a). These macrofossil deposits have been used primarily for dating the emergence of Antarctic coastal areas to generate relative sealevel curves (Adamson \& Pickard 1986, Baroni \& Orombelli 1991, Colhoun et al. 1992, Zwartz et al. 1997, Pallàs et al. 1997). All of the emerged beaches around Antarctica have Holocene marine limits which are less than $35 \mathrm{~m}$ above sea level (Fig. 6), in contrast to the marine limits across the Arctic which range in elevation by hundreds of metres (Andrews 1970, Forman et al. 1997). These emerged beaches reflect minimal isostatic uplift around Antarctica during this period (Colhoun et al. 1992) when the rates of relative sea-level rise were markedly decelerating (Chappell 1983, Fairbanks 1989, Pirazzoli 1996).

The principal species that have been used for dating Antarctic beaches have been bivalve molluscs (Fig. 6), especially Laternula elliptica and Adamussium colbecki (Fig. 4a \& b). These species thrive in protected low-energy nearshore habitats rather than exposed high-energy environments where their wafer-thin shells would be crushed. Adamussium, because it lives on the sediment surface (unlike Laternula which lives in the sediments), is particularly vulnerable to wave action (Berkman 1994b, Berkman \& Prentice 1996). Nearshore habitat conditions which are suitable for Adamussium colonization are reflected in sediments cored in West McMurdo Sound from the Dry Valley Drilling Project(McGinnis 1981).

DVDP 8-10 (Fig. 7), which was collected from a prograding delta that formed in association with glacial meltwater stream runoff from Taylor Valley (Fig. 3a), reveals that Adamussium continuously colonized sandy sediments in this area after $3900 \mathrm{yr} \mathrm{BP}$. This corrected radiocarbon-age was derived from AMS-radiocarbon analyses and is 1400 yrs younger than previously determined from conventional radiocarbon analyses of an Adamussium fragment from the same core depth (Stuiver et al. 1976, McKelvey 1981 Elston \& Bressler 1981). Prior to this mid-Holocene period, which also is reflected by the ages of molluscan fossils from adjacent emerged beaches (Fig. 6), Adamussium was absent while pebble and granule conglomerates were being deposited under high-energy coastal conditions (Fig. 7). The underlying diamictite from DVDP 8-10 is assumed to have been associated with suspension current sedimentation and profuse glacial ice-rafting (McKelvey 1981). These sedimentary data along with general ecological requirements of Adamussium (Berkman 1994b), suggest that its occurrence in emerged beaches around Antarctica (Fig. 6) was influenced by relative sea-level changes as well as the expansion of sea ice and the creation of low-energy nearshore marine habitats after the mid-Holocene.

Around the East Antarctic margin, offshore sediments indicate that open-water conditions existed from 10700 to 7300 yr BP (Domack et al. 1991). Petrel stomach oil deposits 
also suggest that the Bunger Hills area was deglaciated by $10000 \mathrm{yr}$ BP with increased access to open water from 8000 to $6000 \mathrm{yr} \mathrm{BP}$ (Verkulich \& Hiller 1994). Between 11770 and 10325 yr BP, Adélie penguin rookeries existed at Cape Hickey $\left(76^{\circ} 05^{\prime} \mathrm{S}\right)$ along the Victoria Land coast (Baroni \& Orombelli 1994a), which indicates that there was open water in the Ross Sea in the early Holocene. However, it has only been since 6000 yr BP when Adélie penguins began continuously to occupy rookeries north of the Drygalski Ice Tongue $\left(75^{\circ} 24^{\prime} \mathrm{S}\right)$ in the Terra Nova Bay region (Fig. 8). Marine sedimentary deposits with terrigenous and biogenous components support the notion that the Drygalski Ice Tongue has been present since the mid-Holocene (Krissek 1988), several thousand years after the Terra Nova Drift retreated from this region of the Ross Sea (Denton et al. 1989, Licht et al. 1996).

Given that the Drygalski Ice Tongue is a primary forcing factor for the Terra Nova Bay polynya (Kurtz \& Bromwich 1985 ) and that Adélie penguins require access to open water (Fraser et al. 1992), it is suggested that that polynya has been present in the western Ross Sea since the mid-Holocene (Berkman 1997). As the Terra Nova Bay polynya may stimulate up to $20 \%$ of the sea-ice production in the Ross Sea (Gallée 1997), the data indicate that there has been substantially more sea ice in the Ross Sea since the mid-Holocene. This inference is supported by higher abundances of sea-ice diatoms (Fragilariopis curta) in Ross Sea bottom sediments since the mid-Holocene (Cunningham 1997). Lower phytoplankton productivity in Lallemand Fjord, Antarctic Peninsula, also has been attributed to extensive sea ice coverage from 6700 to $4700 \mathrm{yr} \mathrm{BP}$ (Shevenell et al. 1996). This increased sea-ice production in the Ross Sea, Antarctic Peninsula and from elsewhere around the continent would have contributed to the abrupt change in the deuterium and methanesulfonic acid concentrations which has been identified in the Taylor Dome ice core from Victoria Land after $6000 \mathrm{yr}$ BP (Steig et al. in press).

In addition to increased sea-ice extent, across East Antarctica there was an expansion of outlet glaciers through ice shelves and ice tongues during the mid-Holocene (Domack et al. 1991). Subsequent glacial advances along East Antarctica during the mid-Holocene are reflected further by moraines which formed in the Bunger Hills after $6200 \mathrm{yr}$ BP (Adamson \& Colhoun 1992) and in the Windmill Islands after $5500 \mathrm{yr} \mathrm{BP}$ (Goodwin 1996). In the Antarctic Peninsula region, emerged marine deposits suggest that there were re-advances of the George VI Ice Shelf after 6500 yr BP (Sugden \& Clapperton $1980)$ as well as glacial re-advances on James Ross Island from around 7000 to $5000 \mathrm{yr}$ BP (Ingólfsson et al. 1992, Björck et al. 1996) and the South Shetland Islands after 6800 yr BP (Clapperton 1990). In the Ross Sea, there were glacial advances in the Terra Nova Bay area after $5000 \mathrm{yr}$ BP (Baroni \& Orombelli 1994b).

Significant changes in the hydrological cycle following the mid-Holocene also have been identified elsewhere on Earth. For example, by $6000 \mathrm{yr}$ BP most of the deglacial impacts on global sea levelhad been completed (Chappell 1983, Fairbanks 1989, Pirazzoli 1996). There is geoarchaeological evidence from the Peruvian coast that the EI Niño/Southern Oscillation originated between 6000 and $5000 \mathrm{yr} \mathrm{BP}$ (Sandweiss et al. 1996). Climate and cultural changes of that period also have been recognized in the Atacama desert in southern Chile (Grosjean et al. 1997). Glaciers also began fluctuating in tempo across the Andes after 5000 yr вP (Clapperton \& Sugden 1988), suggesting that there has been a synchronous climate response by Antarctic and other Southern Hemisphere glacial systems since the mid-Holocene (Clapperton 1990). Significant glacier advances during the early-middle Holocene have been identified in cold and dry regions of the Arctic which are thought to be more sensitive to precipitation than to air temperature changes (Miller \& De Vernal 1992). Environmental conditions on the Tibetan plateau, which is important in influencing atmospheric circulation in the Northern Hemisphere were warmer and wetter during the early to mid-Holocene. Across the latitudinal belt $8.9-26.6^{\circ} \mathrm{N}$, lake levels during the Holocene have been uniformly low since 5000 yr вP (Kutzbach \& Street-Perrott 1985). These hydrolgic changes are further reflected by decreased atmospheric methane concentrations (Blunier et al. 1995) and abrupt changes in atmospheric circulation which have been recorded from the equator to the poles (Stager \& Mayewski 1997) during the early to mid-Holocene.

Climate models suggest that the seasonal insolation cycle in the Northern Hemisphere between 12000 and $6000 \mathrm{yr}$ BP could have increased summer sea surface temperatures in the tropical Atlantic, enhanced the northern African summer monsoon and modified the global hydrological cycle (COHMAP 1988, Kutzbach \& Liu 1997). Coral geochemistry from the Great Barrier Reef indicates that increased temperatures during the mid-Holocene also led to enhanced evaporation in the tropical western Pacific around $5350 \mathrm{yr} \mathrm{BP}$ (Gagan et al. 1998). Extratropical transport of atmospheric moisture from these source areas may have influenced the sea-ice and glacial changes around Antarctica during the midHolocene. This Antarctic environmental feedback with the hydrological cycle is consistent with polar-tropical atmospheric linkages that have been observed during the last two decades (Gloersen 1995) as well as inferred during the mid-Holocene (Stager \& Mayewski 1997) and the last 124 000 yrs (Thompson et al. 1997).

Widespread changes in terrestrial (outlet glaciers), marine (sea ice) and atmospheric (moisture transport) phenomena in the Antarctic coastal zone indicate that there was circumpolar environmental transition which originated between 8500 and $4500 \mathrm{yr}$ BP. Along with the synchronous environmental changes associated with the hydrological cycle in other regions of the Earth, the composite datasets from the Antarctic coastal zone suggest that there was a global climate shift during the mid-Holocene. 


\section{Conclusions}

Emerged marine deposits in Antarctic coastal areas provide an accessible circumpolar framework for assessing environmental changes on a continental scale during the Late Quaternary. Together, emerged marine fossils and sediments indicate that the configuration of the Antarctic ice margins has oscillated approximately in phase with the interstadial, glacial and Holocene climate conditions that have occurred around the Earth. Moreover, synchronous environmental changes in the coastal zone surrounding Antarctica reveal the imprint of a mid-Holocene climate shifts connected with the hydrological cycle. Innovative interdisciplinary research strategies, coordinated among nations and scientific programs on a continental scale (Weller \& Lorius 1989, Goodwin 1997), are needed to investigate further these environmental connections and feedbacks between the circum-Antarctic coastal system and the Earth's climate.

\section{Acknowledgements}

This review represents the collective efforts of the authors, who gratefully acknowledge the generous support from their respective national Antarctic research programs. We would like to thank Drs Alistair Crame and Andrew McMinn for their thoughtful comments which have greatly improved this manuscript.

\section{References}

ADAMSON, D.A. \& COLhoun, E.A. 1992. Late Quaternary glaciation and deglaciation of the Bunger Hills, Antarctica. Antarctic Science, 4. 435-446.

Adamson, D. \& Pickard, J. 1983. Late Quaternary ice movement across the Vestfold Hills, East Antarctica. In Oliver, R.L., James, P.R. \& JAGO, J.B., eds. Antarctic earth science. Canberra: Australian Academy of Science, 465-469.

ADAMSON, D. \& PICKARD, J. 1986. Cainozoic history of the Vestfold Hills. In PICKARD, J., ed. Antarctic Oasis: terrestrial environments and history of the Vestfold Hills. Sydney: Academic Press, 99-139.

Alley, R.B. \& Whillans, 1.M. 1991. Changes in the West Antarctic Ice Sheet. Science, 254, 959-963.

Alley, R.B., MaYewski, P.A., Sowers, T., Stuiver, M., TAYlor, K.C. \& Clark, P.U. 1997. Holocene climate instability: a prominent, widespread event $8200 \mathrm{yr}$ ago. Geology, 25, 483-486.

ANDERSON, J.G. 1906. On the geology of Graham Land. Geological Institute of Uppsala Bulletin, 7, 19-71.

ANDREWS, J.T. 1970. A geomorphological study of Post-Glacial uplift. London: Institute of British Geographers, $156 \mathrm{pp}$.

Arche, A., López-Martinez, J., Serrano, E. \& Martínez de Pisón, E. 1996. Marine land forms and deposition. In LóPEz-MARTinez, J., THомsоn, M.R.A., Thомsоn, J.W. et al., eds. Geomorphological map of Byers Peninsula, Livingston Island. BAS GEOMAP series, sheet 5-a, 1:25000, with supplementary text. Cambridge: British Antarctic Survey, 35-42.

Bard, E., Hamelin, B., Fairbanks, R.G. \& Zindler, A. 1990. Calibration of the ${ }^{14} \mathrm{C}$ timescale over the past 30000 years using mass spectrometric U-Th ages from Barbados corals. Nature, 345, 405-410.
Baroni, C. 1990. The Hells Gate and Backstairs Passage Ice Shelves, Victoria Land, Antarctica. Memorie della Societa Geologica Italiana, 34, 123-144.

Baron, C.\& Orombelli, G. 1989. Glacial geology and geomorphology of Terra Nova Bay (Victoria Land, Antarctica). Memorie della Societa Geologica Italiana, 33, 171-193.

Baroni, C. \& Orombelli, G. 1991 . Holocene raised beaches at Terra Nova Bay, Victoria Land, Antarctica. Quaternary Research, 36, 157-177

Baroni, C. \& Orombelli, G. 1994a. Abandoned penguin rookeries as Holocene paleoclimatic indicators in Antarctica. Geology, 22, 23-26.

Baron, C. \& Orombelli, G. 1994b. Holocene glacier varitations in the Terra Nova Bay area (Victoria Land, Antarctica). Antarctic Science, 6, 497-505.

Baroni, C., Belluomini, G., Branca, M.E., Improta, S. \& Orombelli, G. 1991. Radiocarbon dates from Terra Nova Bay (Victoria Land, Antarctica): conventional and calibrated ages. Memorie della Societa Geologica Italiana, 46, 81-92.

Barsch, D. \& MaUbacher, R. 1986. Beittäge zut Vergletscherungsgeschichte und zure Reliefwicklung der Südshetland Insel. Zeitschrift für Geomorphologie, 61, 25-37.

BEGET, J.E. 1983. Radiocarbon-dated evidence of worldwide early Holocene climate change. Geology, 11, 389-393.

BeHL, R.J. \& KeNNETT, J.P. 1996. Brief interstadial events in the Santa Barbara basin, NE Pacific, during the past 60 kyr. Nature, 379, 243246.

Berkman, P.A. 1992. Circumpolar distribution of Holocene marine fossils in Antarctic beaches. Quaternary Research, 37, 256-260.

Berkman, P.A. 1994a. Geochemical signatures of meltwater in Antarctic coastal marine molluscs during the Holocene. Memoirs of the National Institute of Polar Research, Special Issue No. 50, 49-84.

Berkman, P.A. 1994b. Epizoic zonation on growing scallop shells in McMurdo Sound, Antarctica. Journal of Experimental Marine Biology and Ecology, 179, 49-67.

Berkman, P.A. 1997. Ecological variability in Antarctic coastal environments: past and present. In Battaglia, B., Valencia, J. \& Walton, D.W.H., eds. Antarctic communities. Cambridge: Cambridge University Press, 349-357.

Berkman, P.A. In press. Indicator species for interpreting environmental variability in the Antarctic coastal zone. Korean Journal of Polar Research.

Berkman, P.A. \& Forman, S.L. 1996. Pre-bomb radiocarbon and the reservoir correction for calcareous marine species in the Southern Ocean. Geophysical Research Letters, 23, 633-636.

Berkman, P.A. \& Prentice, M.L. 1996. Pliocene extinction of Antarctic pectinid mollusks. Science, 271, 1606-1607.

Berkman, P.A., Goad, C. \& Kwon, J.H. 1998. Global Positioning System (GPS) static sites along the Victoria Land Coast, Antarctica Antarctic Journal of the United States, 34(2), 44-45.

Birkenmayer, K. 1993. Quaternary geology of Hope Bay, Trinity Peninsula, West Antarctica. Bulletin of the Polish Academy of Science, 41, 99-114.

Bjorck, S., HJort, C., Ingolfsson, O.\& SkoG, G. 1991. Radiocarbon dates from the Antarctic peninsula - problems and potential. In LowE, J.J., ed. Radiocarbon dating: recent applications and future potential. Quaternary Proceedings, 1, 55-65.

Buórck, S., Olsson, S., Ellis-Evans, C., Hakansson, H., Humlum, O. \& DE LiRIO, J.M. 1996. Late Holocene palaeoclimatic records from lake sediments on James Ross Island, Antarctica. Palaeogeography, Palaeoclimatology, Palaeoecology, 121, 195-220.

Blunier, T., Chappellaz, J., Schwander, J., Stauffer, B. \& Raymaud, D. 1995. Variations in atmospheric methane concentration during the Holocene epoch. Nature, 374, 46-49. 
Borman, P. \& Fritzsche, D., eds. 1995. The Schirmacher Oasis, Queen Maud Land, East Antarctica, and its surroundings. Darmstadt: Justus Perthes Gotha, $448 \mathrm{pp}$.

Broecker, W.S. 1963. Radiocarbon ages of Antarctic materials Polar Record, 11, 472-473.

BroeCKer, W.S. \& WALTON, A.A. 1959. Radiocarbon from nuclear tests. Science, 130, 309-314.

Broecker, W.S., Peng, T.-H., Ostlund, G. \& Stuiver, H. 1985. The distribution of bomb radiocarbon in the ocean. Journal of Geophysical Research, 90, 6953-6970.

Burgess, J.S., Spate, A.P.\& Shevlin, J. 1994. The onset of deglaciation in the Larsemann Hills, Eastern Antarctica. Antarctic Science, 6, $491-495$.

Burton, H.R. 1981. Chemistry, physics and evolution of Antarctic saline lakes. Hydrobiologia, 82, 339-362.

Cameron, R.L. 1964. Glaciological studies at Wilkes Station, Budd Coast, Antarctica. Antarctic Research Series, 2, 1-36.

Cameron, R.L. \& GoldthwatT, R.D. 1961. The US-IGY contribution to Antarctic geology. International Association of Scientific Hydrology Publiscations, 55, 7-13.

Chahine, M.T. 1992. The hydrological cycle and its inlfuence on climate. Nature, 359, 373-379.

Chapman-Smith, M. 1981. The Taylor Formation (Holocene) and its macrofaunas, Taylor Dry Valley, Antarctica. Antarctic Research Series, 33, 365-378.

CHAPPELL, J. 1983. Evidence for smoothly falling sea level relative to north Queensland, Australia, during the past 6000 yr. Nature, 302, 406-408.

Cias, P., Petit, J.R., Jouzel, J., Lorius, C., Barkov, N.I., Lipenkov, V. \& Nicolaiev, V. 1992. Evidence for an early Holocene climatic optimum in the Antarctic deep ice-core record. Climate Dynamics, 6, 169-177

Clapperton, C.M. 1990. Quaternary glaciations in the Southern Ocean and Antarctic Peninsula area. Quaternary Science Reviews, 9, 229-252

Clapperton, C.M. \& Sugden, D.E. 1982. Late Quaternary glacial history of George VI Sound area, West Antarctica. Quaternary Research, 18, 243-267

Clapperton, C.M. \& Sugden, D.E. 1988. Holocene glacier fluctuations in South America and Antarctica. Quaternary Science Reviews, 7, 185-198.

ClaRk, J.A.\& LiNGLE, C.S. 1979. Predicted relative sea-level changes (18 000 years BP to present) caused by Late-Glacial retreat of the Antarctic Ice Sheet. Quaternary Research, 11, 279-298.

COHMAP Members. 1988. Climatic changes of the last 18000 years: observations and model simulations. Science, 241, 1043-1052.

ColHoun, E.A. 1997. A review of geomorphological research in Bunger Hills and expansion of the East Antarctic Ice Sheet during the Last Glacial Maximum. In Ricci, C.A., ed. The Antarctic region: geological evolution and processes. Siena: Museo Nazionale dell' Antartide, 801-807

Colhoun, E.A., Mabin, M.C.G., Adamson, D.A. \& Kirk, R.M. 1992. Antarctic ice volume and contribution to sea-level fall at $20000 \mathrm{yr}$ BP from raised beaches. Nature, 358, 316-319.

Cunningham, W.L. 1997. The use of modern and fossil diatom assemblages as climate Proxies in the Central and Western Ross Sea, Antarctica. Masters Thesis, University of Colorado, $233 \mathrm{pp}$.

Curl, J.E. 1980. A glacial history of the South Shetland Island, Antarctica. Institute of Polar Studies Report, 63, 1-129.

DAvid, T.W.E. \& Priestley, R.E. 1909. Geological observations in Antarctica by the British Antarctic Expedition, 1907-1909. In SHACKLETON, E.H. The Heart of the Antarctic; being the story of the British Antarctic Expedition, 1907-1909. Volume 2. London: William Heinemann, 268-314.

DEACON, G.E.R. 1937. The hydrology of the Southern Ocean. Discovery Report, 15, 3-122.
DeACon, G.E.R. 1982. Physical and biological zonation in the Southern Ocean. Deep-Sea Research, 29, 1-16.

Debenham, F. 1920. A new mode of transportation by ice: the raised marine muds of south Victoria Land (Antarctica). Quarterly Journal of the Geological Society of London, 75, 51-76.

Denton, G.H., Bockheim, J.G., Wilson, S.C. \& Stuiver, M. 1989. Late Wisconsin and Early Holocene glacial history, inner Ross Embayment, Antarctica. Quaternary Research, 31, 151-182.

DOMACK, E.W. 1992. Modern carbon-14 ages and reservoir corrections for the Antarctic Peninsula and Gerlache Strait area. Antarctic Journal of the United States, 27(5), 63-64.

Domack, E.W., Jull, A.J.T. \& NAKaO, S. 1991. Advance of East Antarctic outlet glaciers during the Hypsithermal: implications for the volume state of the Antarctic ice sheet under global warming. Geology, 19, 1059-1062.

Domack, E.W., Ishman, S.E., Stein, A.B., McClennen, C.E. \& Jull, A.J.T. 1995. Late Holocene advance of the Muller Ice Shelf, Antarctic Peninsula: sedimentological, geochemical and paleontological evidence. Antarctic Science, 7, 159-170

DomaCk, E.W., JULl, A.J.T., ANDERSON, J.B., LiniCK, T.W.\& Williams, C.R. 1989. Application of tandem accelerator mass-spectrometer dating to Late Pleistocene-Holocene sediments of the East Antarctic continental shelf. Quaternary Research, 3, 277-287.

DREWRY, D.J. 1975. Initiation and growth of the East Antarctic ice sheet. Journal of the Geological Society of London, 131, 255-273.

DREWRY, D.J. 1983. The surface of the Antarctic Ice Sheet. In DreWry, D.J., ed. Glaciological and geophysical folio. Sheet 2. Cambridge: Scott Polar Research Institute.

DREWRY, D.J., JORDAN, S.R.\& JANKOWSKI, E. 1982. Measured properties of the Antarctic ice sheet: Surface configuration, ice thickness, volume and bedrock characteristics. Annals of Glaciology, 3, $83-91$.

Eglinton, T.I., Benitez-Nelson, B.C., Pearson, A., McNichol, A.P., Bauer, J.E. \& Druffel, E.R.M. 1997. Variability in radiocarbon ages of individual organic compounds from marine sediments. Science, 277, 796-799.

ELSTON, D.P. \& BRESSLER, S.L. 1981. Magnetic stratigraphy of DVDP drill cores and Late Cenozoic history of Taylor Valley, Transantarctic Mountains, Antarctica. Antarctic Research Series, 33, 365-378

EmSLIE, S.D. 1995. Age and taphonomy of abandoned penguin rookeries in the Antarctic Peninsula region. Polar Record, 179 409-418.

Fabel, D., Stone, J., Fifield, L.K. \& Cresswell, R.G. 1997 Deglaciation of the Vestfold Hills, East Antarctica: preliminary evidence from exposure dating of three subglacial erratics. In RiccI, C., ed. The Antarctic region: geological evolution and processes. Siena: Museo Nazionale dell' Antartide, 820-834.

FAIRBANKS, R.G. 1989. A 17 000-yr glacio-eustatic sea level record: influence of glacial melting rate on the Younger Dryas event and deep-ocean circulation. Nature, 342, 637-641

FerRar, H.T. 1907. Report on the field geology of the region explored during the Discovery Antarctic Expedition, 1901-1903. Natural History Reports of the National Antarctic Expedition (Geology), 1, $1-100$.

Folland, C.K., KaRL, T.R. \& VinniKov, K.Y. 1990. Observed climate variations and change. Climate change, the IPCC assessment. WMOI UNEP. Cambridge: Cambridge University Press, 201-238.

Forman, S.L., Weihe, R., Lubinski, D., Tarasov, G., Korsun, S. \& Matishov, G. 1997. Holocene relative sea-level history of Franz Josef Land, Russia. Geological Society of America Bulletin, 109 , 1116-1133.

Francois, R., Altabet, M.A., Yu, E.-F., Sigman, D.M., Bacon, M.P., Frank, M., Bohrmann, G., Bareille, G. \& Labeyrie, L.D. 1997. Contribution of Southern Ocean surface-water stratification to low atmospheric $\mathrm{CO}_{2}$ concentrations during the last glacial period. Nature, 389, 929-935. 
Fraser, W.R., Trivelpiece, W.Z., Ainley, D.G. \& Trivelpiece, S.G. 1992. Increases in Antarctic penguin populations: reduced competition with whales or a loss of sea ice due to environmental warming? Polar Biology, 11, 525-51.

FulFORD-SMITH, S.P. \& Sikes, E.L. 1996. The evolution of Ace Lake, Antarctica, determined from sedimentary diatom assemblages. Palaeogeography, Palaeoclimatology, Palaeoecology, 124, 73-86.

Gagan, M.K., Ayliffe, L.K., Hopley, D., Cali, J.A., Mortimer, G.E., Chappell, J., McCulloch, M.T. \& Head, M.J. 1998. Temperature and surface-ocean water balance of the Mid-Holocene tropical western Pacific. Science, 279, 1014-1018.

GALLĖE, H. 1997. Air-sea interaction over Terra Nova Bay during winter: simulation with a coupled atmosphere-polynya model. Journal of Geophysical Research, 102, 13 835-13 849.

GEYH, M.A \& SCHLEICHER, H. 1990. Absolute age determination: physical and chemical dating methods and their application. Berlin: Springer-Verlag, $503 \mathrm{pp}$

Giovinetto, M.B. \& Bentley, C.R. 1985. Surface balance in ice drainage systems of Antarctica. Antarctic Journal of the United States. 20(4), 6-13.

Gloersen, P. 1995. Modulation of hemispheric sea-ice cover by ENSO events. Nature, 373, 503-506.

Goodwin, I.D. 1993. Holocene deglaciation, sea-level change, and the emergence of the Windmill Islands, Budd Coast, Antarctica. Quaternary Research, 40, 70-80.

Goodwin, I.D. 1996. A mid to late Holocene readvance of the Law Dome ice margin, Budd Coast, East Antarctica. Antarctic Science, $8,395-406$.

GooDwin, I.D. 1997. Global change and the Antarctic - an overview of the SCAR GLOCHANT Programme. Global Change Newsletter, 29, 13-14

Gordon, J.E. \& Harkness, D.D. 1992. Magnitude and geographic variation of the radiocarbon content in Antarctic marine life: implications of reservoir corrections in radiocarbon dating. Quaternary Science Reviews, 11, 697-708.

Grosjean, M., Nunez, L., Cartajena, I. \& Messerli, B. 1997. MidHolocene climate and culture change in the Atacama Desert, Northern Chile. Quaternary Research, 48, 239-246.

HalL, B.L. 1997. Geological assessment of Antarctic Ice Sheet stability. Doctoral Dissertation, University of Maine, $324 \mathrm{pp}$.

HANSOM, J.D. 1979. Radiocarbon dating of a raised beach at $10 \mathrm{~m}$ in the South Shetland Islands. British Antarctic Survey Bulletin, No. 49, 287-288.

Hansom, J.D. \& Funt, C.P. 1989. Holocene ice fluctuations on Brabant Island, Antarctic Peninsula. Antarctic Science, 1, 165-166.

HarkNESS, D.D. 1979. Radiocarbon dates from Antarctica. British Antarctic Survey Bulletin, No. 47, 43-59.

Harris, P.T., O'Brien, P.E., Sedwick, P. \& Truswell, E.M. 1996 Late Quaternary history of sedimentation on the Mac. Robertson Shelf, East Antarctica: problems with ${ }^{14} \mathrm{C}$ dating of marine sediment cores. Papers and Proceedings of the Royal Society of Tasmania, $130,47-53$

Hayashi, M. \& Yoshida, Y. 1994. Holocene raised beaches in the Lutzhow-Holm Bay Region, East Antarctica. Memoirs of the National Institute of Polar Research Special Issue, No. 50, 49-84.

Hays, J.D., Imbrie, J. \& Shackleton, N.J. 1976. Variations in the Earth's orbit: pacemaker of the ice ages. Science, 194, 1121-1132.

Hendy, C.H., Neall, V.E. \& Wilson, A.T. 1969. Recent marine deposits from Cape Barne, McMurdo Sound, Antarctica. New Zealand Journal of Geology and Geophysics, 12, 707-712.

Hiller, A., Wand, U., Kampf, H. \& Stackebrandt, W. 1988. Occupation of the Antarctic continent by petrels during the past 35000 years: inferences from a ${ }^{14} \mathrm{C}$ study of stomach oil deposits. Polar Biology, 9, 69-77.

Hiort, C., IngólfFson, Ô., Moller, P. \& Lirio, J.M. 1997. Holocene glacial history and sea-level changes on James Ross Island, Antarctic Peninsula. Journal of Quaternary Science, 12, 259-273.

Hughen, K.A., Overpeck, J.T., Lehman, S.J., Kashgarian, M., Southon, J., Peterson, L.C., Alley, R. \& Sigman, D.M. 1998. Deglacial changes in ocean circulation from an extended radiocarbon calibration. Nature, 391, 65-68.

Igarashi, A., Harada, N. \& Moriwaki, K. 1995. Marine fossils of 30$40 \mathrm{ka}$ in raised beach deposits and late Pleistocene glacial history around Lutzow-Holm Bay, East Antarctica. Proceedings NIPR Symposium on Antarctic Geoscience, No. 8, 219-229.

INGÓlFsSON, O., HJORT, C., BJORCK, S. \& SMITH, R.I.L. 1992. Late Pleistocene and Holocene glacial history of James Ross Island, Antarctic Peninsula. Boreas, 21, 209-222.

JACOBS, S.S. 1992. Is the Antarctic ice sheet growing? Nature, 360, 29-33.

JOHN, B.S. \& SUGDEN, D.E. 1971. Raised marine features and phases of glaciation in the South Shetland Islands. British Antarctic Survey Bulletin, No. 24, 45-111.

Jouzel, J., Lorius, C., Petit, J.R., Genthon, C., Barkov, N.I., Kotlyakov, V.M. \& Petrov, V.M. 1987. Vostok ice core: a continuous isotope temperature record over the last climatic cycle (160000 years). Nature, 329, 403-408.

Jouzel, J., Raisbeck, G., Benoist, J.P., Yiou, F., Lorius, C., Raynaud, D., Petit, J.R., Barkov, N.L., Korotkevitch, Y.S. \& Kotlyakov, V.M. 1989. A comparison of deep Antarctic ice cores and their implications for climate between 65,00 and 15000 years ago. Quaternary Research, 31, 135-150

Kelloga, T.B., KellogG, D.E. \& Stuiver, M. 1990. Late Quaternary history of the southwestern Ross Sea: evidence from debris bands on the McMurdo Ice Shelf. Antarctic Research Series, 50, 24-56.

KING, J.C. \& TURNER, J. 1997. Antarctic meteorology and climatology. Cambridge Cambridge University Press, 407 pp.

KiRK, R.M. 1991. Raised beaches, Late Quaternary sea levels and deglacial sequences on the Victoria Land Coast, Antarctica. In Gillieson, D. \& Fitzsimons, S., eds. Quaternary Research in Australian Antarctica. Special Publication No. 3. Canberra: Australian Defence Force Academy, 85-105.

Kitagawa, H. \& van der Plicht, J. 1998. Atmospheric radiocarbon calibration to $45000 \mathrm{yr}$ BP: late glacial fluctuations and cosmogenic isotope production. Science, 279, 1187-1190.

KOROTKEVICH, YE.S. 1971. Quaternary marine deposits and terraces in Antarctica. Soviet Antarctic Expedition Information Bulletin, 8 , 185-190.

KRISSEK, L.A. 1988. Sedimentation history of the Terra Nova Bay region, Ross Sea, Antarctica. Antarctic Journal of the United States, 23(5), 104-105.

KURTz, D.D. \& Bromwich, D.H. 1985. A recurring, atmospherically forced polynya in Terra Nova Bay. Antarctic Research Series, 43, 177-201.

Kutzbach, J.E. \& LiU, Z. 1997. Response of the African monsoon to orbital forcing and ocean feedbacks in the middle Holocene. Science, 278, 440-443.

Kutzbach, J.E. \& Street-Perrott, F.A. 1985. Milankovitch forcing of fluctuations in the level of tropical lakes from 18 to $0 \mathrm{kyr}$ BP. Nature, 317, 130-134.

Labeyrie, L.D., Pichon, J.J., Labracherie, M., Ippolito, P., Duprat, J. \& DuplessY, J.C. 1986. Melting history of Antarctica during the past 60000 years. Nature, 322, 701-706.

Licht, K.J., Jennings, A.E., Andrews, J.T. \& Williams, K.M. 1996. Chronology of Jate Wisconsin ice retreat from the western Ross Sea, Antarctica. Geology, 24, 223-226.

Lintinen, P. \& Nenonen, J. 1997. Glacial history of the Vesfjella and Heimefrontfjella nunatak ranges in Western Dronning Maud Land, Antarctica. In Riccl, C., ed. The Antarcic region: geological evolution and processes. Siena: Museo Nazionale dell' Antartide, 845-852. 
López-Martínez, J., de Pisón, E.M. \& Arche, A. 1992. Geomorphology of Hurd Peninsula, Livingston Island, South Shetland Islands. In YoshiDA, Y., ed. Recent progress in Antarctic earth science. Tokyo: Terra Scientific Publishing Company, 751-756.

López-Martínez, J., Thomson, M.R.A. \& Thomson, J.W., eds. 1996. Geomorphological map of Byers Peninsula, Livingston Island. BAS GEOMAP series, sheet 5-a, 1:25000, with supplementary text. Cambridge: British Antarctic Survey, $65 \mathrm{pp}$.

Lorius, C., Merlivat, L., Jouzel, J. \& Pourchet, M. 1979. A 30000 yr climatic record from Antarctic ice. Nature, 280, 642-648.

Mabin, M.C.G. $1985 .{ }^{14} \mathrm{C}$ ages for "Heroic Era" penguin and seal bones from Inexpressible Island, Terra Nova Bay, North Victoria Land. New Zealand Antarctic Record, 6, 24-25.

MABIN, M.C.G. 1986. ${ }^{14} \mathrm{C}$ ages for "Heroic Era" penguin and seal remains from Cape Evans, McMurdo Sound. New Zealand Antarctic Record, 7, 19-20.

Maemoku, H., Miura, H., Siagusa, S. \& Moriwaki, K. 1997 Stratigraphy of the Late Quaternary raised beach deposits in the northern part of Langhovde, Lützow-Holm Bay, East Antarctica. Proceedings of the NIPR Symposium on Antarctic Geoscience, 10 , 178-186.

Martinez-Macchiavello, J.C., Tatur, A., Servant-Vildary, S. \& DeL VALLE, R. 1996. Holocene environmental change in a marineestuarine-lacustrine sediment sequence, King George Island, South Shetland Islands. Antarctic Science, 8, 313-322.

McGinnis, L.D., ed. 1981. Dry Valley Drilling Project. Antarctic Research Series, 33, 465 pp.

MCKeLVEY, B.C. 1981. The lithospheric logs of DVDP cores 10 and 11, Eastern Taylor Valley. Antarctic Research Series, 33, 63-94.

Meguro, H., Yoshida, Y. Uchio, T. Kigoshi, K. \& Sugawara, K. 1964. Quaternary marine sediments and their geological dates with reference to the geomorphology of Kronprins Olav Kyst. In ADIE, R.J., ed. Antarctic geology. Amsterdam: North Holland Publishing, 73-80.

Melles, M., Kulbe, T., Verkulich, S.R., Pushina, Z.V. \& Hubberten, H.-W. 1997. Late Pleistocene and Holocene environmental history of Bunger Hills, East Antarctica, as revealed by fresh-water and episheif lake sediments: In RICCl, C., ed. The Antarctic region: geological evolution and processes. Siena: Museo Nazionale dell' Antartide, 809-820.

Melles, M., Verkulich, S.R. \& HermicheN, W.D. 1994. Radiocarbon dating of lacustrine and marine sediments from the Bunger Hills, East Antarctica. Antarctic Science, 6, 375-378.

Mercer, J.H. 1978. West Antarctic Ice Sheet and $\mathrm{CO}_{2}$ greenhouse effect: a threat of disaster. Nature, 271, 321-325.

Michel, R.L. \& Druffel, E.M. 1983. Radiocarbon in the Weddell Sea as observed in a deep-sea coral and in krill. Geophysical Research Letters, 10, 190-192.

Miller, G.H. \& Brigham-Grette, J. 1989. Amino acid geochronology: resolution and precision in carbonate fossils. Quaternary International, 1, 111-128.

Miller, G.H. \& DE Vernal, A. 1992. Will greenhouse warming lead to Northern Hemisphere ice-sheet growth? Nature, 355, 244-246.

MORIWAKI, K. 1974. Tyutsuo-Horumu wan tôgan no ryûki teisen to kai tasseki no ${ }^{14} \mathrm{C}$ nendai (Radiocarbon datings of fossil shells on raised beaches on the east coasta of Lutzow-Holm Bay, East Antarctica). Nankyoku Shiryó (Antarctic Record), 48, 82-90.

MoRIWAKI, K. 1976. Syôwa kiti fukin no rogan no chikei to tairikuhyô enpenbu no chigakuteki kansatsu (Glacio-geomorphological observations in and around ice-free areas in the vicinity of Syowa Station, Antarctica). Nankyoku Shiryô (Antarctic Record), 57, 24-55.

NAKAdA, M. \& LAMBecK, K. 1988. The melting history of the Late Pleistocene Antarctic ice sheet. Nature, 333, 36-40.

Nichols, R.L. 1960. Geomorphology of Marguerite Bay area, Palmer
Peninsula, Antarctica. Bulletin of the Geological Society of America, 71, 1421-1450.

NichoLs, R.L. 1961a. Characteristics of beaches formed in polar climates. American Journal of Science, 259, 694-708.

Nichols, R.L. 1961b. Characteristics of beaches formed in polar climates. IGY World Data Center A, Glaciological Report, No. 4. 103-121.

Nichols, R.L. 1968. Coastal geomorphology, McMurdo Sound Antarctica. Journal of Glaciology, 7, 449-478.

Nogami, M. 1977. Higashi Nankyoku Purinsu Orafu kaigan no ryûki teisen ni tsuite (On the raised along the Prince Olav Coast, East Antarctica). Nihon Dai-4-ki Gakkai Yôshishû, 6, 10.

OLSEN, E.A. \& BROECKER, W.S. 1961. Lamont natural radiocarbon measurements VII. Radiocarbon, 3, 141-175.

Омото, K. 1976. Tohoku University radiocarbon measurements III Scientific Report of Tohoku University 7th Series, 26, 126-150

Омото, K. 1977. Geomorphic development of the Soya Coast. East Antarctica. Chronological interpretation of raised beaches based on levelling and radiocarbon datings. Scientific Report of Tohoku University 7th Series, 27, 95-148.

OMoto, K. 1978. Tohoku University radiocarbon measurements VI Scientific Report of Tohoku University 7th Series, 28, 101-116

Омото, K. 1983. The problem and significance of radiocarbon geochronology in Antarctica. In OLIVER, R.L., JAMES, P.R. \& J AGO, J.B., eds. Antarctic earth science. Canberra: Australian Academy of Science, 450-452

Omoto, K., MAKITA, H. \& KoSEKI, Y. 1974. Tohoku University radiocarbon measurements II. Scientific Report of Tohoku University 7 th Series, 24, 205-209.

Orombelli, G., Baroni, C. \& Denton, G.H. 1990. Late Cenozoic glacial history of the Terra Nova Bay region, Northern Victoria Land, Antarctica. Geografia Fisica e Dinamica Quaternaria, 13, 139-163.

Pallás, R., James, T.S., Sàbat, F., Vilaplana, J.M. \& Grant, D.R. 1997. Holocene uplift in the South Shetland Islands: evaluation of tectonics and glacial isostasy. In Ricci, C., ed. The Antarctic region: geological evolution and processes. Siena: Museo Nazionale dell' Antartide, 861-868.

PECK, L.S. \& BREY, T. 1996. Bomb signals in old Antarctic brachiopods. Nature, 380, 207-208.

PeLtiER, W.R. 1994. Ice age paleotopography. Science, 265, 195-201

Péwé, T.L., Rivard, N.R. \& Llano, G.A. 1959. Mummified seal carcasses in the McMurdo Sound region, Antarctica. Science, 130, 716.

PICKARD, J. 1985. The Holocene fossil marine macrofauna of the Vestfold Hills, East Antarctica. Boreas, 14, 189-202.

PICKARD, J.ed. 1986. Aniarctic Oases: terrestrial environments and history of Antarctica. Sydney: Academic Press, $367 \mathrm{pp}$

Pickard, J. \& ADAmson, D. 1983a. Holocene marine deposits and ice retreat, Vestfold Hills, Antarctica $32 \pm 5$ ka. In CHAPPELL, J.M.A. \& GrIndrod, A., eds. Proceedings of the First CLIMANZ Conference Canberra: Australian National University, 20-21.

Pickard, J. \& Adamson, D. 1983b. Holocene marine deposits and ice retreat, Vestfold Hills, Antarctica $7 \pm 2 \mathrm{ka}$ (to present). In CHAPPELL, J.M.A. \& Grindrod, A., eds. Proceedings of the First CLIMANZ Conference. Canberra: Australian National University, 110.

Pickard, J. \& Seppelt, R.D. 1984. Holocene occurrence of the moss Bryum algens Card. in the Vestfold Hills, Antarctica. Journal of Bryology, 13, 209-217.

Pickard, J., Adamson, D.A. \& Heath, C.W. 1986. The evolution of Watts Lake, Vestfold Hills, East Antarctica, from marine inlet to freshwater lake. Palaeogeography, Palaeoclimatology, Palaeoecology, 53, 271-288.

Pickard, J., Adamson, D.A., Harwood, D.M., Miller, G.H., Quilty, P.G. \& DelL, R.K. 1988. Early Pliocene marine sediments, coastline and climate of East Antarctica. Geology, 16, 158-161. 
Pielou, E.C. 1991. After the Ice Ages. Chicago: University of Chicago Press, $366 \mathrm{pp}$.

Pirazolli, P.A. 1996. Sea-level changes: the last 20000 years. New York: John Wiley, $211 \mathrm{pp}$.

RABASSA, J. 1983. Stratigraphy of the glacigenic deposits in James Ross Island, Antarctica. In Evenson, E.B., Schluchter, C. \& RaBAsSA, J., eds. Tills and related deposits. Rotterdam: A.A. Balkema, 329-340.

RotT, H., Skvarca, P. \& Nagler, T. 1996. Rapid collapse of northern Larsen Ice Shelf, Antarctica. Science, 271, 788-792.

Ryan, P.G., Steele, W.K., Siegfried, W.R. \& Vogel, J.C. 1992. Radiocarbon dates of snow petrel regurgitations can reveal exposures periods for nunataks in Antarctica. South African Journal of Science, 88, 578-580.

Sandweiss, D.H., Richardson, J.B., Reitz, E.J., Rollins, E.B. \& MaAsch, K.A. 1996. Geoarcheological evidence from Peru for a 5000 year BP onset of El Niño. Science, 273, 1531-1533.

SCHWERDTfEger, W. 1984. Weather and climate of the Antarctic. Developments in Atmospheric Science, No. 15. Amsterdam Else vier, $261 \mathrm{pp}$

Shevenell, A.E., Domack, E.W. \& Kernan, G.M. 1996. Record of Holocene paleoclimate change along the Antarctic Peninsula: evidence from glacial marine sediments, Lallemand Fjord. Papers and Proceedings of the Royal Society of Tasmania, 130, 55-64.

Shotton, F.W., Blundell, D.J. \& Williams, R.E.G. 1968. Birmingham University radiocarbon dates II. Radiocarbon, 10, 200-206.

Shotton, F.W., Blundell, D.J. \& Williams, R.E.G. 1969. Birmingham University radiocarbon dates III. Radiocarbon, 11, 263-270.

SMITH, W.O. ed. 1990. Polar oceanography: parts $A$ and B. New York: Academic Press, $760 \mathrm{pp}$.

SPEDEN, I.G. 1962. Fossiliferous Quaternary marine deposits in the McMurdo Sound region, Antarctica. New Zealand Journal of Geology and Geophysics, 5, 746-777

SPEIR, T.W. \& Cowling, J.C. 1984. Omithogenic soils of the Cape Bird Adélie penguin rookeries, Antarctica. Polar Biology, 2, 199-205.

Stager, J.C. \& MAYewski, P.A. 1997. Abrupt early to mid-Holocene climatic transition registered at the equator and the poles. Science, 276, 1834-1836.

Steig, E.J., Hart, C.P., White, J.W.C., Cunningham, W.L., Davis, M.D. \& SALTZMAN, E.S. In press. Changes in climate, ocean and ice sheet conditions in the Ross Embayment at $6 \mathrm{ka}$. Annals of Glaciology, 27.

Stuiver, M. \& Braziunas, T.F. 1993. Modeling atmospheric ${ }^{14} \mathrm{C}$ influences and ${ }^{14} \mathrm{C}$ ages of marine samples to $10000 \mathrm{BC}$. Radiocarbon, 35, 137-189.

StUIVER, M. \& QUAY, P.D. 1981. Atmospheric ${ }^{14} \mathrm{C}$ changes resulting from fossil fuel $\mathrm{CO}_{2}$ release and cosmic ray flux variability. Earth and Planetary Science Letters, 53, 349-362.

Stuiver, M. \& Reimer, P.J. 1993. Extended ${ }^{14} \mathrm{C}$ data base and revised Calib $3.0{ }^{14} \mathrm{C}$ calibration program. Radiocarbon, 35, 215-230.

Stuiver, M., Denton, G.H. \& Borns, H.W. 1976. Carbon-14 dates of Adamussium colbecki (Mollusca) in marine deposits at New Harbor, Taylor Valley. Antarctic Journal of the United States, 11(2), 86-88.

Stuiver, M., Denton, G.H., Hughes, T.J. \& Fastook, G.L. 1981. History of the marine ice sheet in West Antarctica during the last glaciation: a working hypothesis. In DENTON, G.H. \& Hughes, T.J., eds. The last great ice sheets. New York: John Wiley, 319-436.

Stuiver, M., Quay, P.D. \& Ostlund, H.G. 1983. Abyssal water carbon-14 distribution and the age of the world oceans. Science, 219, 849-851

SUESS, H.E. 1955. Radiocarbon concentration in modern wood. Science, $122,415-417$.

Sugden, D.E. \& Clapperton, C.M. 1980. West Antarctic ice sheet fluctuations in the Antarctic Peninsula region. Nature, 286, 378-381.
Sugden, D.E. \& John, B.S. 1973. The ages of glacier fluctuations in the South Shetland Islands, Antarctica. In vaN ZINDEREN BAKKer. E.M., ed. Paleoecology of Africa and of the surrounding islands and Antarctica, Volume 8. Cape Town: Balkema, 139-159.

Tatur, A. 1989. Ornithogenic soils of the maritime Antarctic. Polish Polar Research, 10, 481-532.

Tatur, A., Myrcha, A.\& Niegodzisz, J. 1997. Formation of abandoned penguin rookery ecosystems in the maritime Antarctic. Polar Biology, 17, 405-417.

Taylor, K.C., Lamorey, G.W., Doyle, G.A., Alley, R.B., Grootes, P.M., Mayewski, P.A., White, J.W.C. \& Barlow, L.K. 1993. The 'flickering switch' of late Pleistocene climate change. Nature, 361 , $432: 436$.

Thompson, L.G., Yao, T., Davis, M.E., Henderson, K.A., MosleyThompson, E., Lin, P.-N., Beer, J., Synal, H.-A., Cole-Dai, J. \& BolzAN, J.F. 1997. Tropical climate instability: the last glacial cycle froma Qinghai-Tibetan ice core. Science, 276, 1821-1825.

Verkulich, S.R. \& Hiller, A. 1994. Holocene deglaciation of the Bunger Hills revealed by ${ }^{14} \mathrm{C}$ measuremens on stomach oil deposits in snow petrel colonies. Antarctic Science, 6, 395-399.

WebB, P.N. \& WrenN, J.H. 1975. Foraminifera from DVDP holes 8.9, and 10, Taylor Valley. Antarctic Journal of the United States. 10(4), 168-169.

WEHMILLER, J.F. 1982. A review of amino acid racemization studies in Quaternary mollusks: stratigraphic and chronologic applications in coastal and interglacial sites, Pacific and Atlantic coasts, United States, United Kingdom, Baffin Island and tropical islands Quaternary Science Reviews, 1, 83-120.

Weller, G. \& LoRIUS, C. 1989. The role of Antarctica in global change: scientific priorities for the International GeosphereBiosphere Programme (IGBP). Cambridge: ICSU Press/SCAR, Scott Polar Research Institute, $28 \mathrm{pp}$

Whitehouse, I.E., Chinn, T.J., Hoeffle, H.C. 1988. Radiocarbon contaminated penguin bones from Terra Nova Bay, Antarctica. New Zealand Antarctic Record, 8(3), 11-23.

YeVteYev, S.A. 1962. Marine terraces along the Antarctic coast. Soviet Antarctic Information Bulletin, 4, 73-76.

Yoshida, Y. 1970. Higashi Nankyoku Purinsu Orafu kaigan no ryûki teisen to enko (Raised beaches and saline lakes on the Prince Olav Coast, East Antarctica). Gendai no Chirigaku, Tokyo: Kokon Shoin, 93-118.

Yoshida, Y. 1973. Rogan no chikei to hyôshô no hendô (Geomorphology of ice-free areas and fluctuation of the ice sheet). In Kusunoki, H., ed. Nankyoku. Tokyo: Kyôritsu Shuppan, 237-281.

YoshidA, Y. 1983. Physiography of the Prince Olav and the Prince Harald Coasts, East Antarctica. Memoirs of the National Institute of Polar Research Series C, 13, 1-83.

YoshIDA, Y. \& MoRIWAKI, K. 1979. Some consideration on elevated coastal features and their dates at Syowa Station, Antarctica. Memoirs of the National Institute of Polar Research. Special Issue, No. 113, 220-226

ZhanG, Q. \& Peterson, J.A. 1984. Geomorphology and Late Quaternary geology of the Vestfold Hills, Antarctica. Australian National Antarctic Research Expedition Reports, 133, I-84.

Zhang, Q., Youyu, X. \& Yuangfang, L. 1983. A preliminary study of the evolution of the post Late Pleistocene Vestfold Hills environment, East Antarctica. In Oliver, R.L., James, P.R. \& J AGO, J.B., eds. Antarctic earth science. Canberra: Australian Academy of Science, 473-477

Zhivago, A.V. \& Esteev, S.A. 1970. Shelf and marine terraces of Antarctica. Quaternaria, 12, 89-114.

Zwartz, D., Lambeck, K., Bird, M. \& Stone, J. 1997. Constraints on the former Antarctic ice sheet from sea-level observations and geodynamic modelling. In RICCI, C., ed. The Antarctic region: geological evolution and processes. Siena: Museo Nazionale dell' Antartide, $821-828$ 